\title{
Biotinylated phosphorus dendrimers as control line in nucleic acid lateral flow tests
}

Laura Vidal, ${ }^{a}$ Alejandra Ben Aissa, Jordi Salabert, ${ }^{a, b}$ José Juan Jara, ${ }^{a, b}$ Adelina Vallribera ${ }^{a, b}$ María Isabel Pividori, ${ }^{a,{ }^{*}}$ Rosa María Sebastián ${ }^{a, b *}$

${ }^{a}$ Department of Chemistry, Universitat Autònoma de Barcelona, Campus de Bellaterra s/n, 08193 Cerdanyola del Vallès, Barcelona, Spain

${ }^{\text {b}}$ Centro de Innovación en Química Avanzada (ORFEO-CINQA). Campus UAB.

Cerdanyola del Vallès, 08193-Barcelona, Spain. 


\section{Index}

S1. Synthesis of (E)-(2-benzylidene-1-methylhydrazinyl) phosphonothioic dichloride.

S2. (E)-(2-benzylidene-1-methylhydrazinyl) phosphonothioic dichloride $\left(\mathrm{CDCl}_{3}\right)$ spectra.

S3. ${ }^{1} \mathrm{H}$ NMR $\left(360 \mathrm{MHz}, \mathrm{CDCl}_{3}\right) \delta(\mathrm{ppm})$ of compound 1.

S4. ${ }^{13} \mathrm{C}$ NMR $\left(90 \mathrm{MHz}, \mathrm{CDCl}_{3}\right) \delta$ (ppm) of compound 1.

S5. ${ }^{31} \mathrm{P}$ NMR $\left(162 \mathrm{MHz}, \mathrm{CDCl}_{3}\right) \delta$ (ppm) of compound $\mathbf{1}$

S6. IR (ATR) $v_{\max }\left(\mathrm{cm}^{-1}\right)$ of compound $\mathbf{1}$.

S7. HR-MS (MALDI-TOF) m/z of compound 1.

S8. ${ }^{1} \mathrm{H}$ NMR $\left(250 \mathrm{MHz}, \mathrm{DMF}-d_{7}\right) \delta(\mathrm{ppm})$ of imine precursor of 3 .

S9. ${ }^{1} \mathrm{H}$ NMR (400 MHz, DMF- $\left.d_{7}\right) \delta(\mathrm{ppm}){ }^{1} \mathrm{H}$ NMR $\left(400 \mathrm{MHz}, \mathrm{DMF}-d_{7}\right) \delta(\mathrm{ppm})$ of compound 3 .

S10. ${ }^{13} \mathrm{C}$ NMR $\left(101 \mathrm{MHz}, \mathrm{DMF}-d_{7}\right) \delta(\mathrm{ppm})$ of compound 3.

S11. ${ }^{31} \mathrm{P}$ NMR (162 MHz, acetone- $\left.d_{6}\right) \delta(\mathrm{ppm})$ of compound 3.

S12. IR (ATR) $v_{\max }\left(\mathrm{cm}^{-1}\right)$ of compound 3.

S13. ${ }^{1} \mathrm{H}$ NMR $\left(250 \mathrm{MHz}, \mathrm{DMF}-d_{7}\right) \delta(\mathrm{ppm})$ of imine precursor of G1-biotin.

S14. ${ }^{1} \mathrm{H}$ NMR (400 MHz, DMF- $\left.d_{7}\right) \delta$ (ppm) of compound G1-biotin.

S15. ${ }^{13} \mathrm{C}$ NMR $\left(101 \mathrm{MHz}, \mathrm{DMF}-d_{7}\right) \delta(\mathrm{ppm})$ of compound G1-biotin.

S16. ${ }^{31} \mathrm{P}$ NMR $\left(162 \mathrm{MHz}, \mathrm{DMF}-d_{7}\right) \delta(\mathrm{ppm})$ of compound G1-biotin.

S17. IR (ATR) $v_{\max }\left(\mathrm{cm}^{-1}\right)$ of compound G1-biotin.

S18. ${ }^{1} \mathrm{H}$ NMR $\left(250 \mathrm{MHz}, \mathrm{DMF}-\mathrm{d}_{7}\right) \delta$ (ppm) of imine precursor of G4-biotin.

S19. ${ }^{1} \mathrm{H}$ NMR (400 MHz, DMF-d $) \delta$ (ppm) of compound G4-biotin.

S20. ${ }^{13} \mathrm{C}$ NMR (101 MHz, DMF-d $) \delta$ (ppm) of compound G4-biotin.

S21. ${ }^{31} \mathrm{P}$ NMR $\left(162 \mathrm{MHz}, \mathrm{DMF}-d_{7}\right) \delta$ (ppm) of compound G4-biotin.

S22. IR (ATR) $v_{\max }\left(\mathrm{cm}^{-1}\right)$ of compound G4-biotin.

S23. AFM images of aggregates of compound G4-biotin in $\mathrm{MeOH}(1 \mathrm{mg} / \mathrm{mL})$ on mica surface.

S24. TEM image of compound G4-biotin using uranyl acetate as negative stain. Diameter distribution histogram is also indicated. 
S25. Preparation and assembly of the lateral flow strips.

S26. Readout of the intensity by the ImageJ software.

S27. Left: Images of strips of LFA tests showing interaction between different biotinylated macromolecules (G1-biotin, G4-biotin, BSA-biotin and IgG-biotin) and free biotin with $5.9010^{-11} \mathrm{~mol} \mathrm{~L}^{-1}$ streptAv-AuNPs. For each experiment, $\mathrm{n}=2$. Right. Table contents: moles of dendrimers and biotin moieties in $\mathrm{mg} \mathrm{mL}^{-1}$ and of $\mu \mathrm{mol} \mathrm{mL}{ }^{-1}$.

S28. Left. LFA images using different concentration of dispensed G1-biotin dendrimers (1:10 water:DMF) as control line, after interaction with $5.9010^{-11} \mathrm{~mol} \mathrm{~L}^{-1}$ streptAvAuNPs. $\mathrm{n}=3$. Right. Table contents: moles of dendrimers and biotin moieties in $\mathrm{mg} \mathrm{mL}^{-}$ ${ }^{1}$ and of $\mu \mathrm{mol} \mathrm{mL}^{-1}$ solutions.

S29. Left. Peaks obtained with the software ImageJ using different concentration of dispensed G1-biotin dendrimers (1:10 water:DMF) as control line, after interaction with $5.9010^{-11}$ mol L ${ }^{-1}$ streptAv-AuNPs. $\mathrm{n}=3$. Right. Table contents: moles of dendrimers and biotin moieties in $\mathrm{mg} \mathrm{mL}^{-1}$ and of $\mu \mathrm{mol} \mathrm{mL}^{-1}$ solutions.

S30. Left. LFA images using different concentration of dispensed G4-biotin dendrimers (9:1, water:DMF) as control line, after interaction with $5.9010^{-11} \mathrm{~mol} \mathrm{~L}^{-1}$ streptAvAuNPs. $\mathrm{n}=3$. Right. Table contents: moles of dendrimers and biotin moieties in $\mathrm{mg} \mathrm{mL}^{-}$ ${ }^{1}$ and of $\mu \mathrm{mol} \mathrm{mL} \mathrm{m}^{-1}$ solutions.

S31. Left. Peaks obtained with the software ImageJ using different concentration of dispensed G4-biotin dendrimers (9:1, water:DMF) as control line, after interaction with $5.9010^{-11} \mathrm{~mol} \mathrm{~L}^{-1}$ streptAv-AuNPs. $\mathrm{n}=3$. Right. Table contents: moles of dendrimers and biotin moieties in $\mathrm{mg} \mathrm{mL}^{-1}$ and of $\mu \mathrm{mol} \mathrm{mL}^{-1}$ solutions.

S32. LFA images using different concentration of signal generating system (streptAvAuNPs) in the conjugation pad and $1 \mathrm{mg} \mathrm{mL}^{-1}$ of dispensed G1-biotin dendrimer (1:10 water:DMF) as control line. $\mathrm{n}=2$.

S33. Peaks obtained with the software ImageJ using different concentration of signal generating system (streptAv-AuNPs) in the conjugation pad and $1 \mathrm{mg} \mathrm{mL}^{-1}$ of dispensed G1-biotin dendrimer (9:1, water:DMF) as control line. $\mathrm{n}=2$.

S34. LFA images using different concentration of signal generating system (streptAvAuNPs) in the conjugation pad and $1 \mathrm{mg} \mathrm{mL}^{-1}$ of dispensed G4-biotin dendrimer (9:1, water:DMF) as control line. $\mathrm{n}=2$.

S35. Peaks obtained with the software ImageJ using different concentration of signal generating system (streptAv-AuNPs) in the conjugation pad and $1 \mathrm{mg} \mathrm{mL}^{-1}$ of dispensed G4-biotin dendrimer (9:1, water:DMF) as control line. $\mathrm{n}=2$. 
S36. Stability study at a $1 \mathrm{mg} \mathrm{mL}^{-1}$ of dispensed G1-biotin dendrimers solutions (9:1, water:DMF) as control line and a concentration of signal generating system (streptAvAuNPs) in the conjugation pad of $2.4510^{-11} \mathrm{~mol} \mathrm{~L}^{-1} . \mathrm{n}=2$.

S37. Peaks obtained with the software ImageJ of the stability study at a $1 \mathrm{mg} \mathrm{mL}^{-1}$ of dispensed G1-biotin dendrimers solutions (9:1, water:DMF) as control line and a concentration of signal generating system (streptAv-AuNPs) in the conjugation pad of $2.4510^{-11} \mathrm{~mol} \mathrm{~L}^{-1} \cdot \mathrm{n}=2$.

S38. Stability study at a $1 \mathrm{mg} \mathrm{mL}^{-1}$ of dispensed G4-biotin dendrimers solutions (9:1, water:DMF) as control line and a concentration of signal generating system (streptAvAuNPs) in the conjugation pad of $2.4510^{-11} \mathrm{~mol} \mathrm{~L}^{-1} \cdot \mathrm{n}=2$.

S39. Peaks obtained with the software ImageJ of the stability study at a $1 \mathrm{mg} \mathrm{mL}^{-1}$ of dispensed G4-biotin dendrimers solutions (9:1, water:DMF) as control line and a concentration of signal generating system (streptAv-AuNPs) in the conjugation pad of $2.4510^{-11} \mathrm{~mol} \mathrm{~L}^{-1} \cdot \mathrm{n}=2$.

S40. Development of the lateral flow strips for the detection of a double-tagged DNA 


\section{S1. Synthesis of $(E)$-(2-benzylidene-1-methylhydrazinyl) phosphonothioic} dichloride.

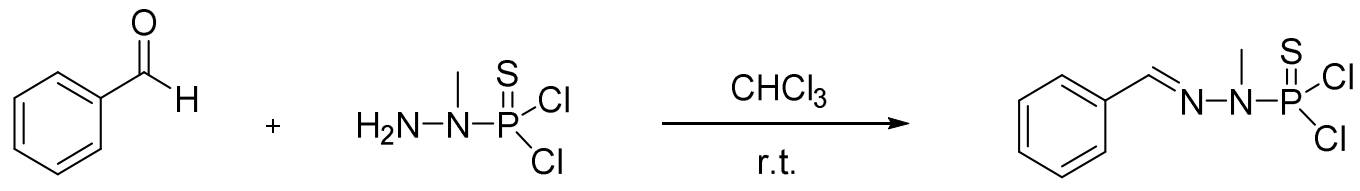

A round-bottom flask was charged with benzaldehyde $(0.478 \mathrm{~mL}, 4.71 \mathrm{mmol}, 1$ equiv) and was cooled to $0^{\circ} \mathrm{C}$. Next, a solution of (1-methylhydrazinyl)phosphonothioic dichloride in chloroform $(0.23 \mathrm{M}, 37.0 \mathrm{~mL}, 8.5 \mathrm{mmol}, 2$ equiv) was added dropwise. The reaction mixture was allowed to warm to ambient temperature and stir for $3 \mathrm{~h}$. Upon completion (judged by NMR), the reaction mixture was filtered over silica-gel using a mixture of dichloromethane:pentane 9:1 as solvent, and concentrated under reduced pressure affording the desired product $(0.955 \mathrm{~g}, 76 \%$ yield $)$ as a colorless solid.

${ }^{1}$ H NMR (360 MHz, Chloroform- $d$ ) $\delta 7.77-7.72(\mathrm{~m}, 2 \mathrm{H}), 7.73-7.70$ (m, 1H), 7.48 $7.38(\mathrm{~m}, 3 \mathrm{H}), 3.51(\mathrm{dd}, J=14.0,0.7 \mathrm{~Hz}, 3 \mathrm{H})$. Spectroscopy data matches with previously reported data. ${ }^{1}$

\footnotetext{
${ }^{1}$ Franc, G.; Badetti, E.; Duhayon, C.; Coppel, Y.; Turrin, C.-O.; Majoral, J.-P.; Sebastian, R.-M. Caminade, A.-M. New J.Chem. 2010, 34, 547-555.
} 


\section{Spectra of new products}

S2. (E)-(2-benzylidene-1-methylhydrazinyl) phosphonothioic dichloride $\left(\mathrm{CDCl}_{3}\right)$
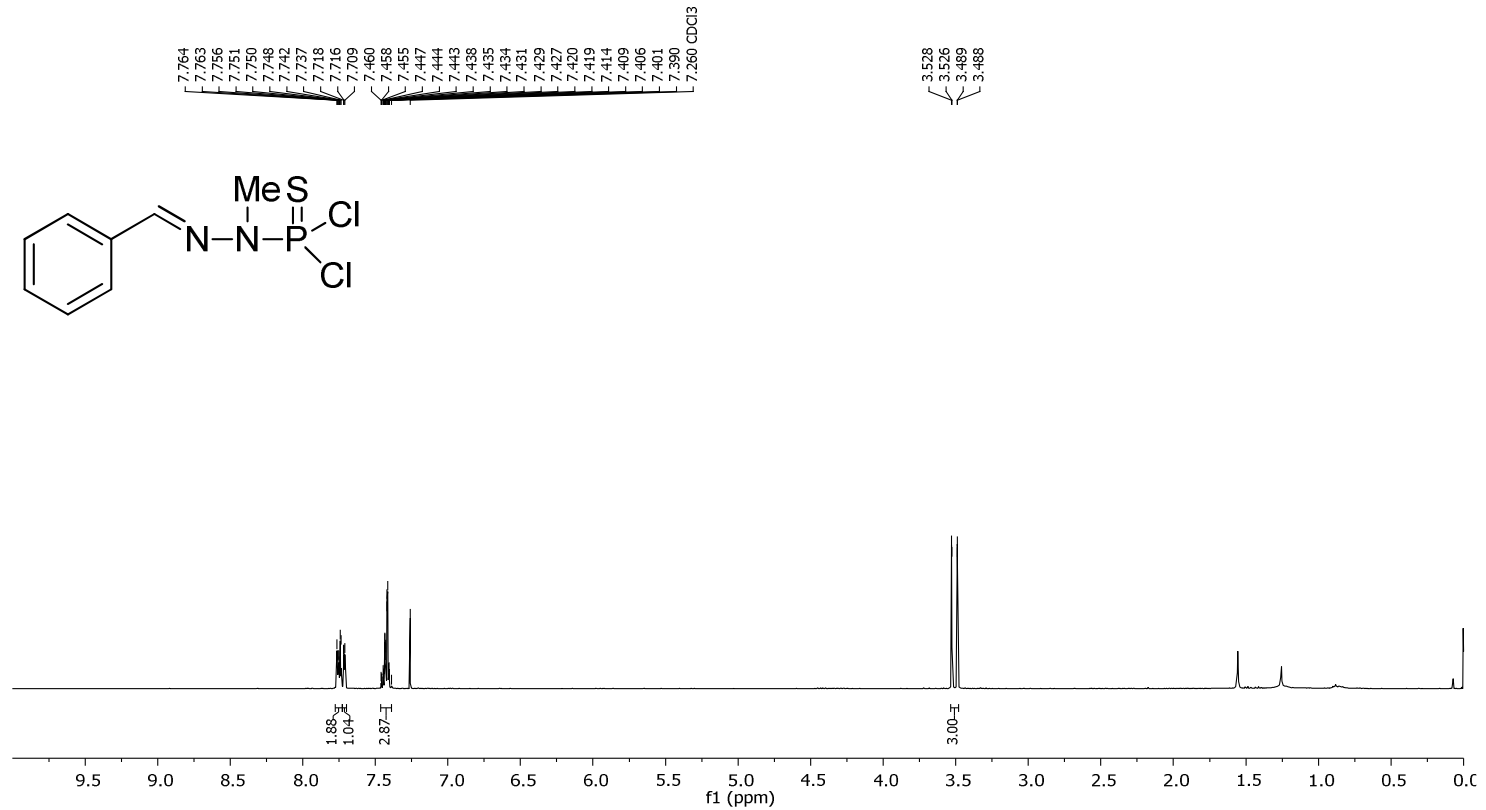

\section{Compound 1}

S3. ${ }^{1} \mathrm{H}$ NMR $\left(360 \mathrm{MHz}, \mathrm{CDCl}_{3}\right) \delta(\mathrm{ppm})$ of compound 1:
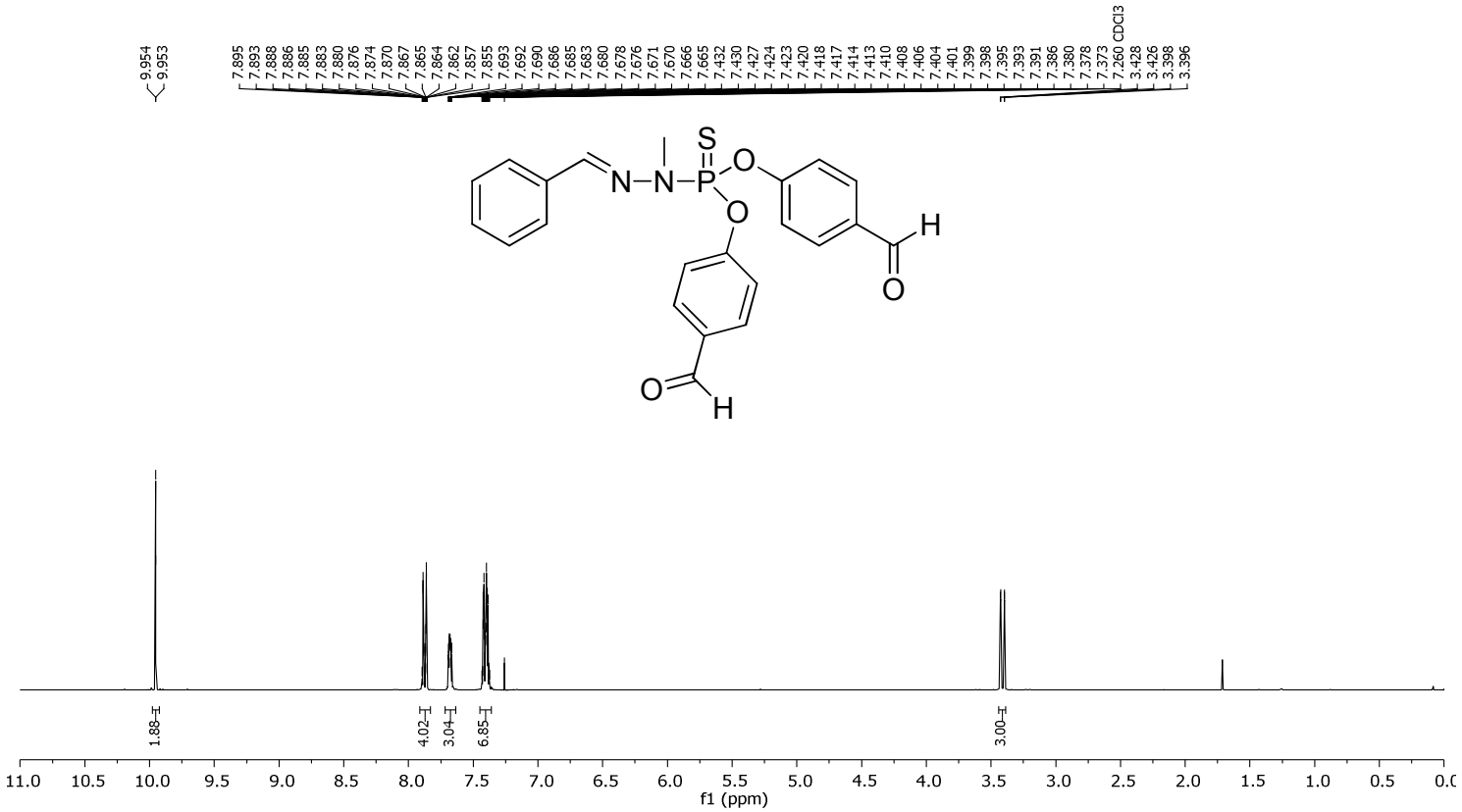
S4. ${ }^{13} \mathrm{C}$ NMR $\left(90 \mathrm{MHz}, \mathrm{CDCl}_{3}\right) \delta$ (ppm) of compound 1:
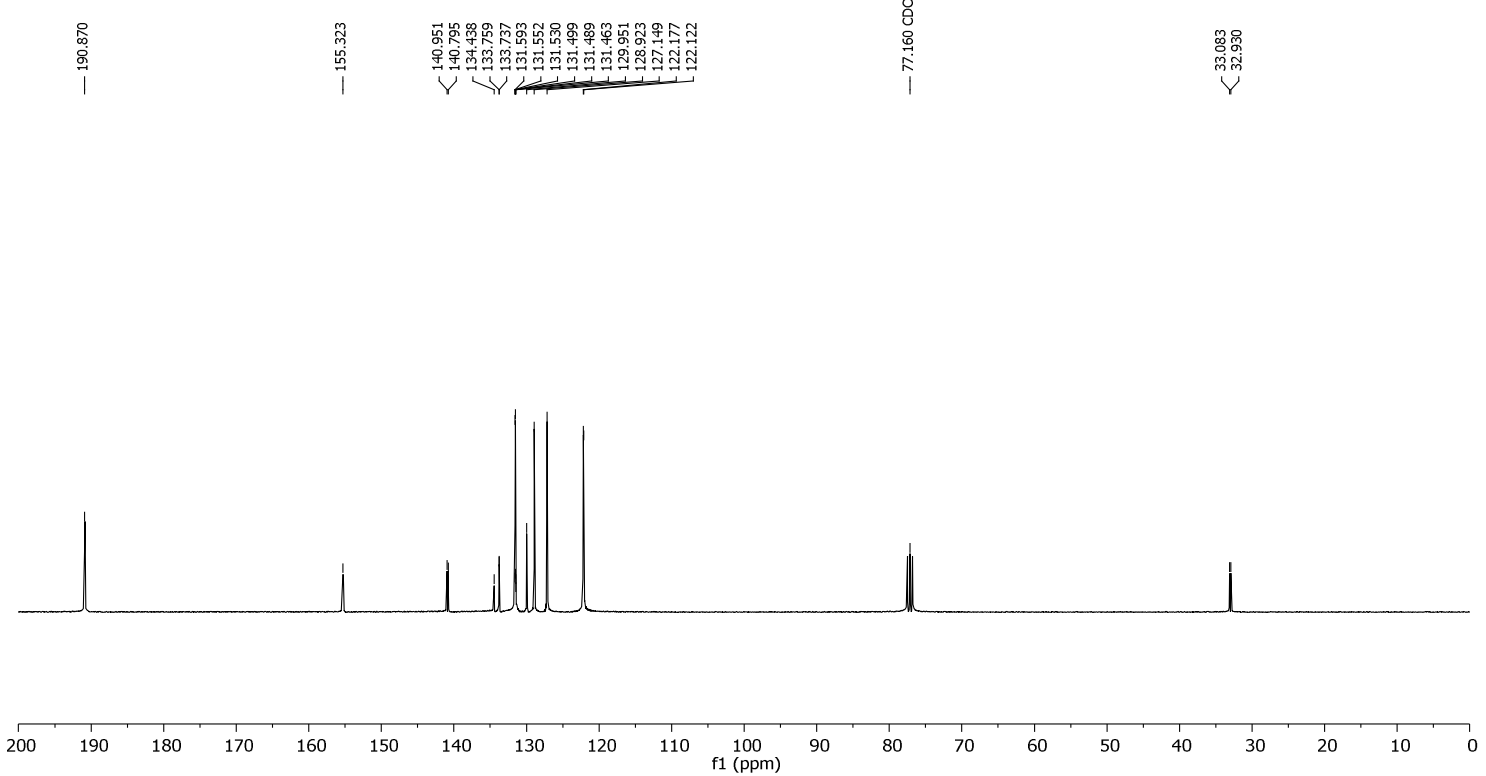

S5. ${ }^{31} \mathrm{P}$ NMR $\left(162 \mathrm{MHz}, \mathrm{CDCl}_{3}\right) \delta$ (ppm) of compound $\mathbf{1}$ :

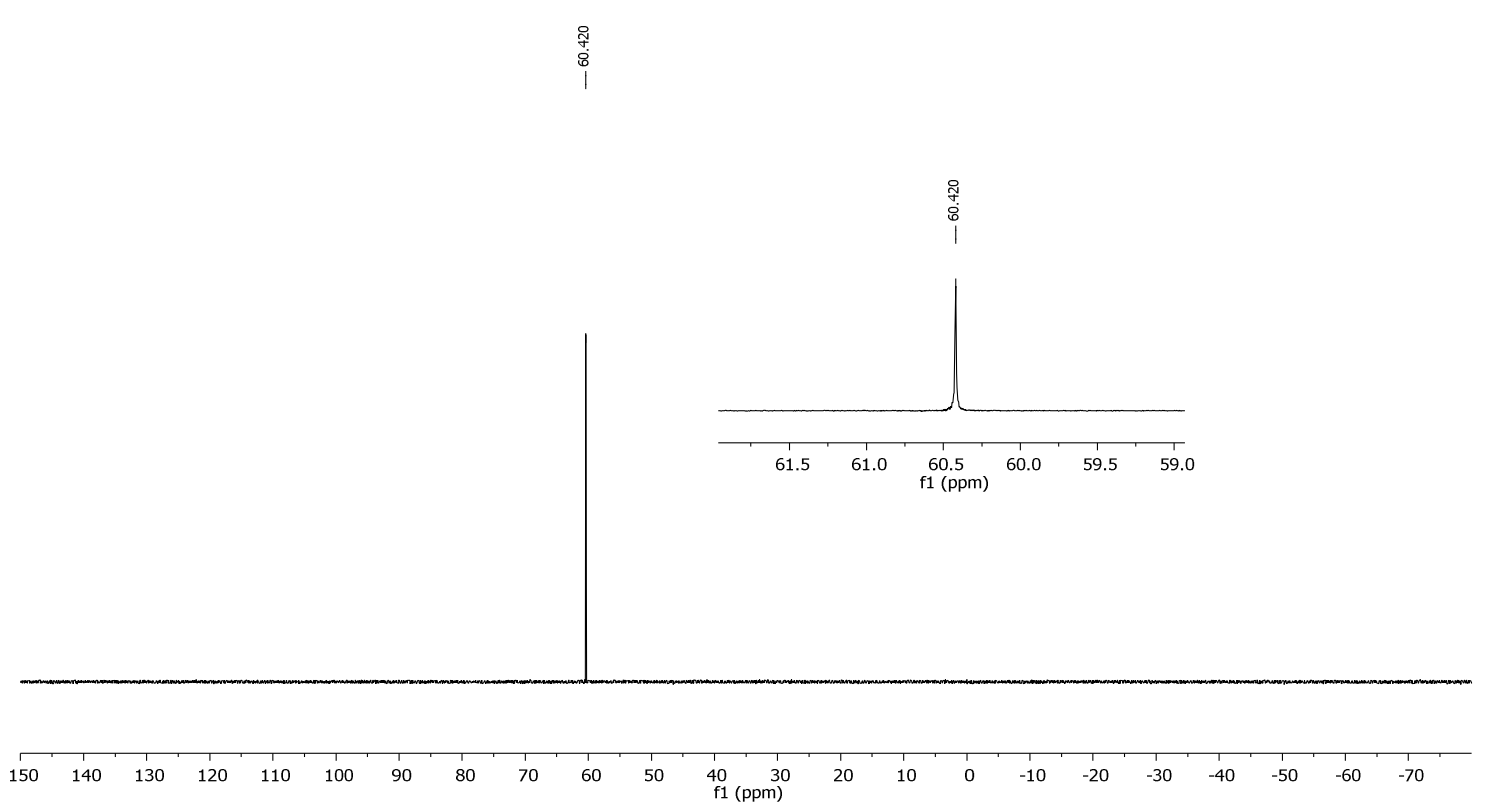


S6. IR (ATR) $v_{\max }\left(\mathrm{cm}^{-1}\right)$ of compound $\mathbf{1}$ :

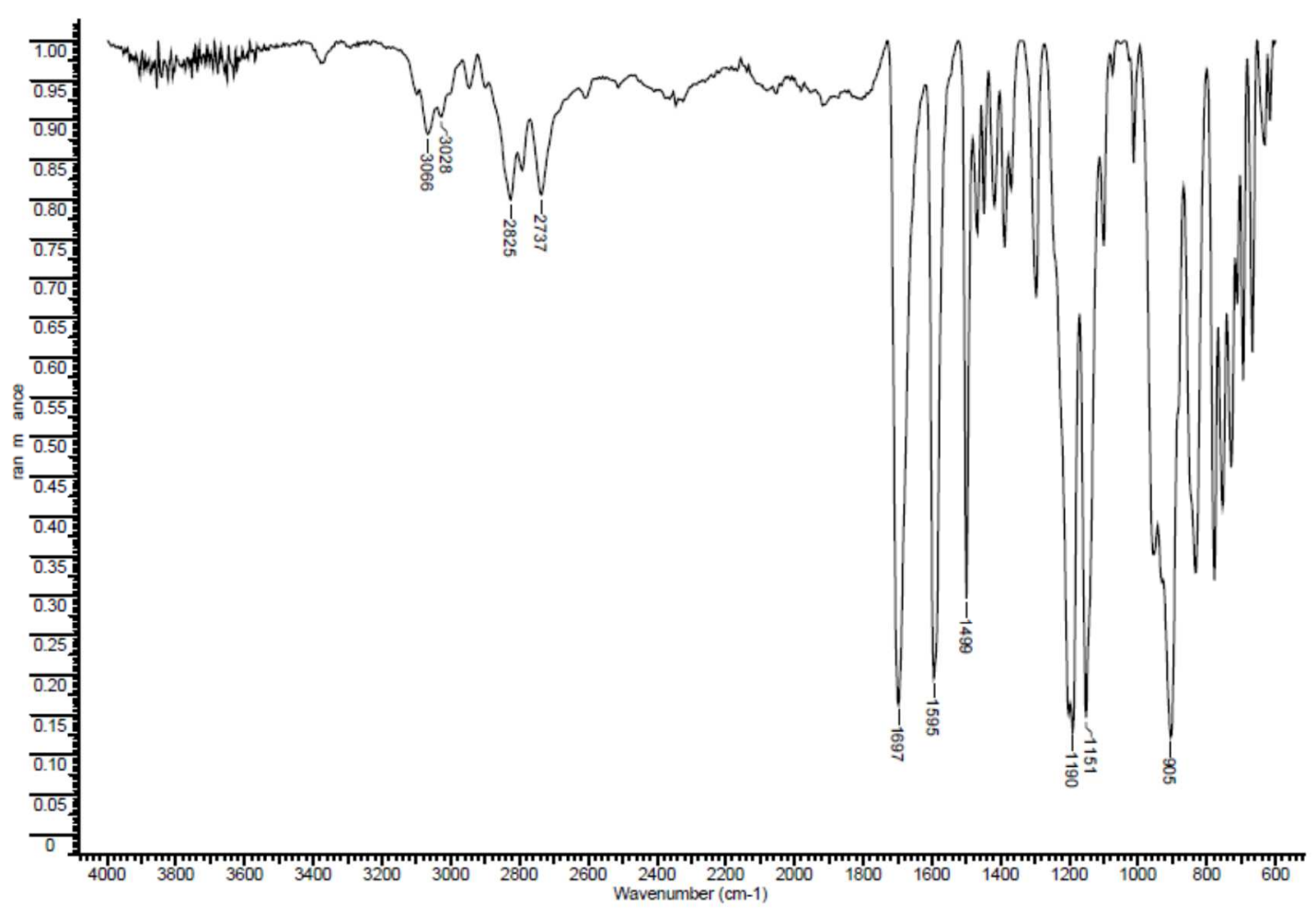

S7. HR-MS (MALDI-TOF) m/z of compound 1:

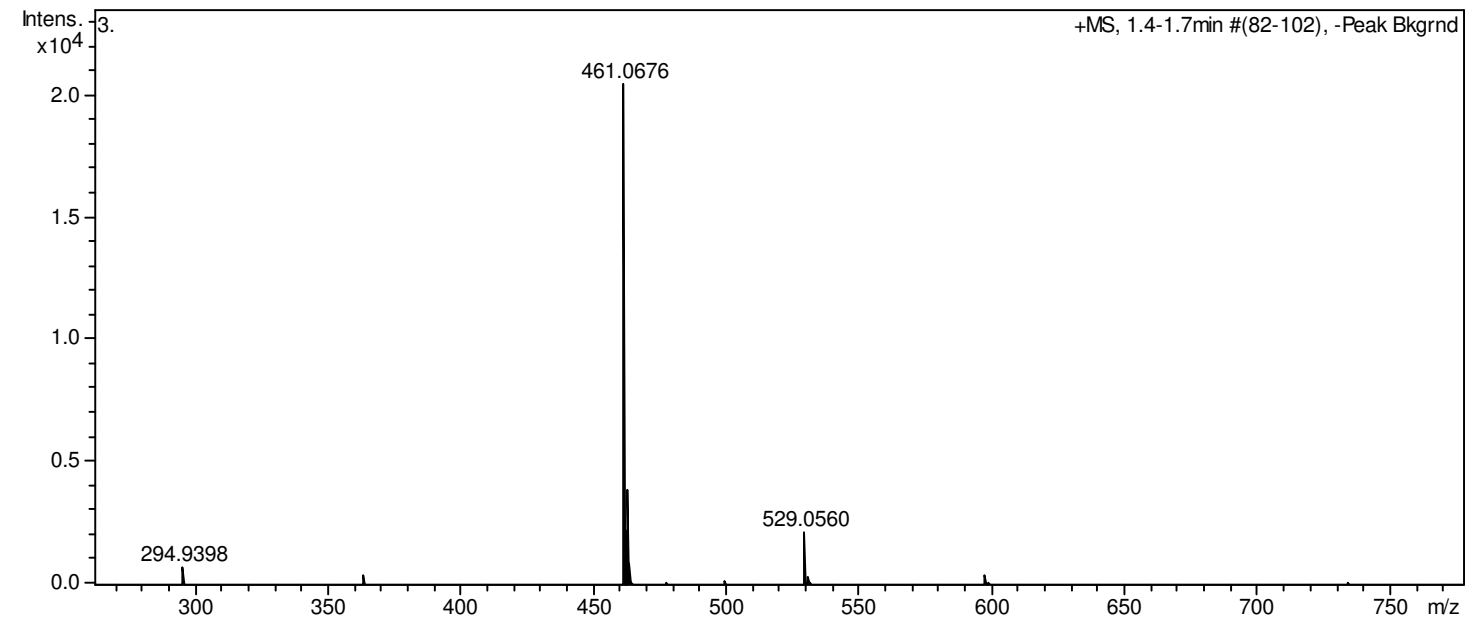

$\begin{array}{llllll}\text { Meas. } \mathrm{m} / \mathrm{z} & \text { Formula } & \mathrm{m} / \mathrm{z} & \text { err }[\mathrm{mDa}] & \text { err }[\mathrm{ppm}] & \mathrm{mSigma}\end{array}$ $\begin{array}{llllll}461.0676 & \mathrm{C} 22 \mathrm{H} 19 \mathrm{~N} 2 \mathrm{Na} \text { O 4 P S } & 461.0695 & 1.9 & 4.2 & 38.3\end{array}$ 


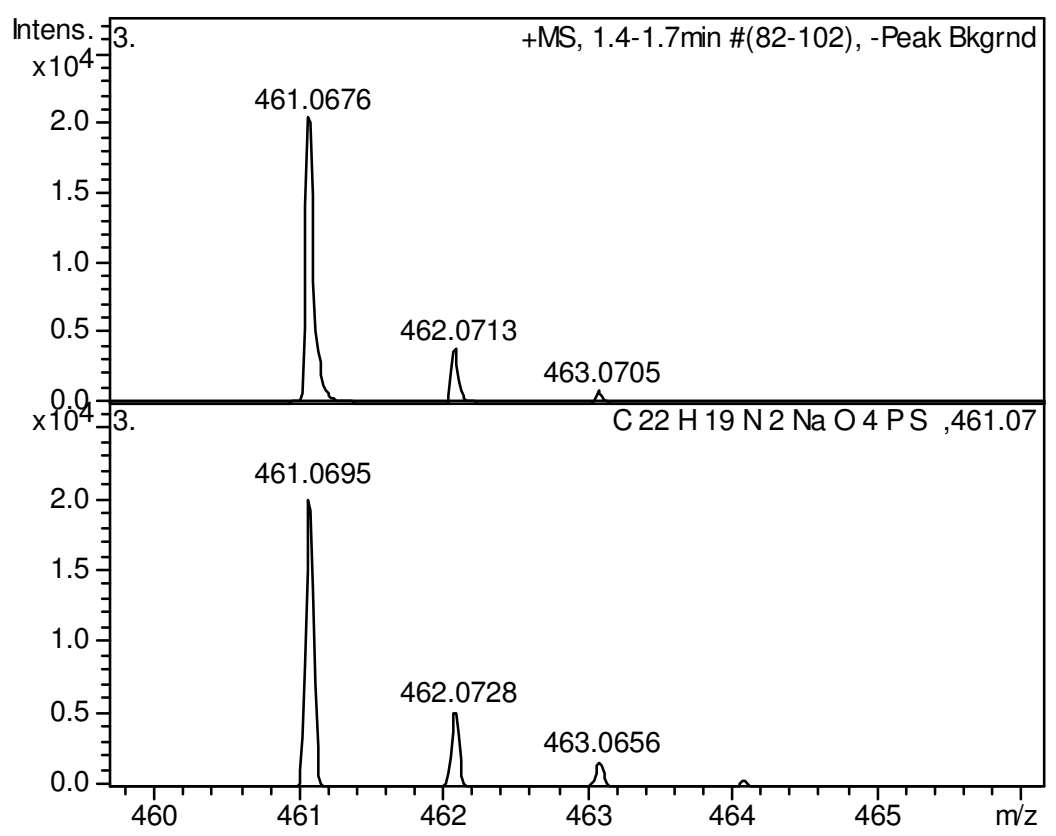

\section{Compound 3}

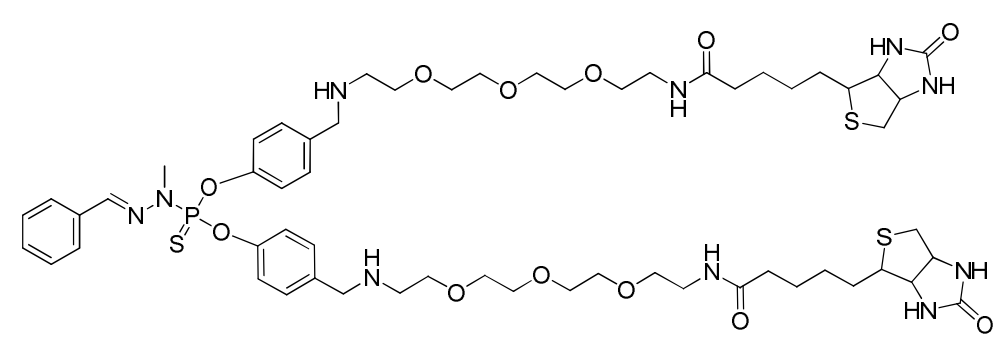

S8. ${ }^{1} \mathrm{H}$ NMR $\left(250 \mathrm{MHz}, \mathrm{DMF}-d_{7}\right) \delta(\mathrm{ppm})$ of imine precursor of 3:

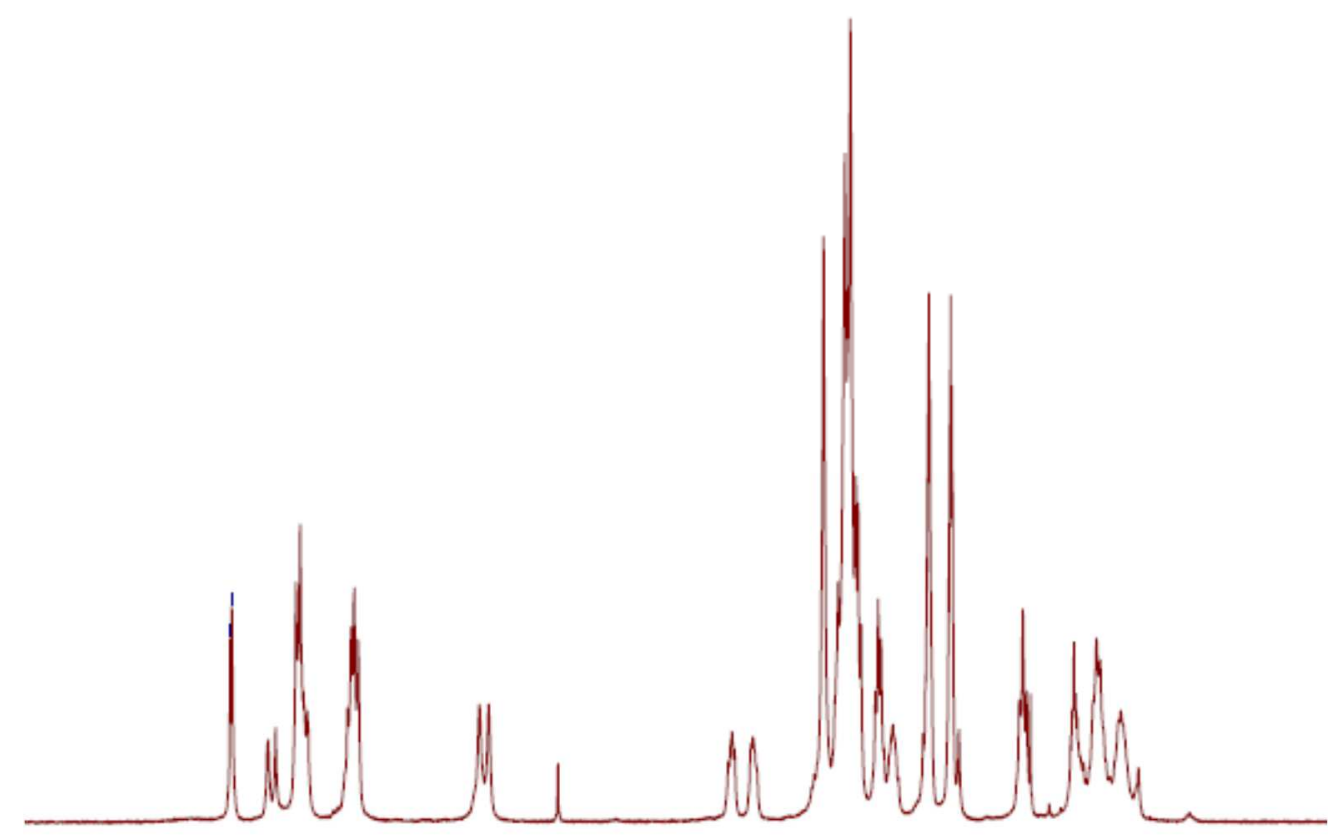

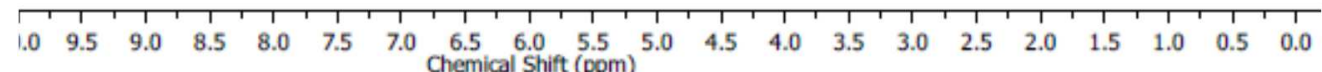


S9. ${ }^{1} \mathrm{H}$ NMR $\left(400 \mathrm{MHz}, \mathrm{DMF}-d_{7}\right) \delta(\mathrm{ppm}) \delta$ (ppm) of compound 3:
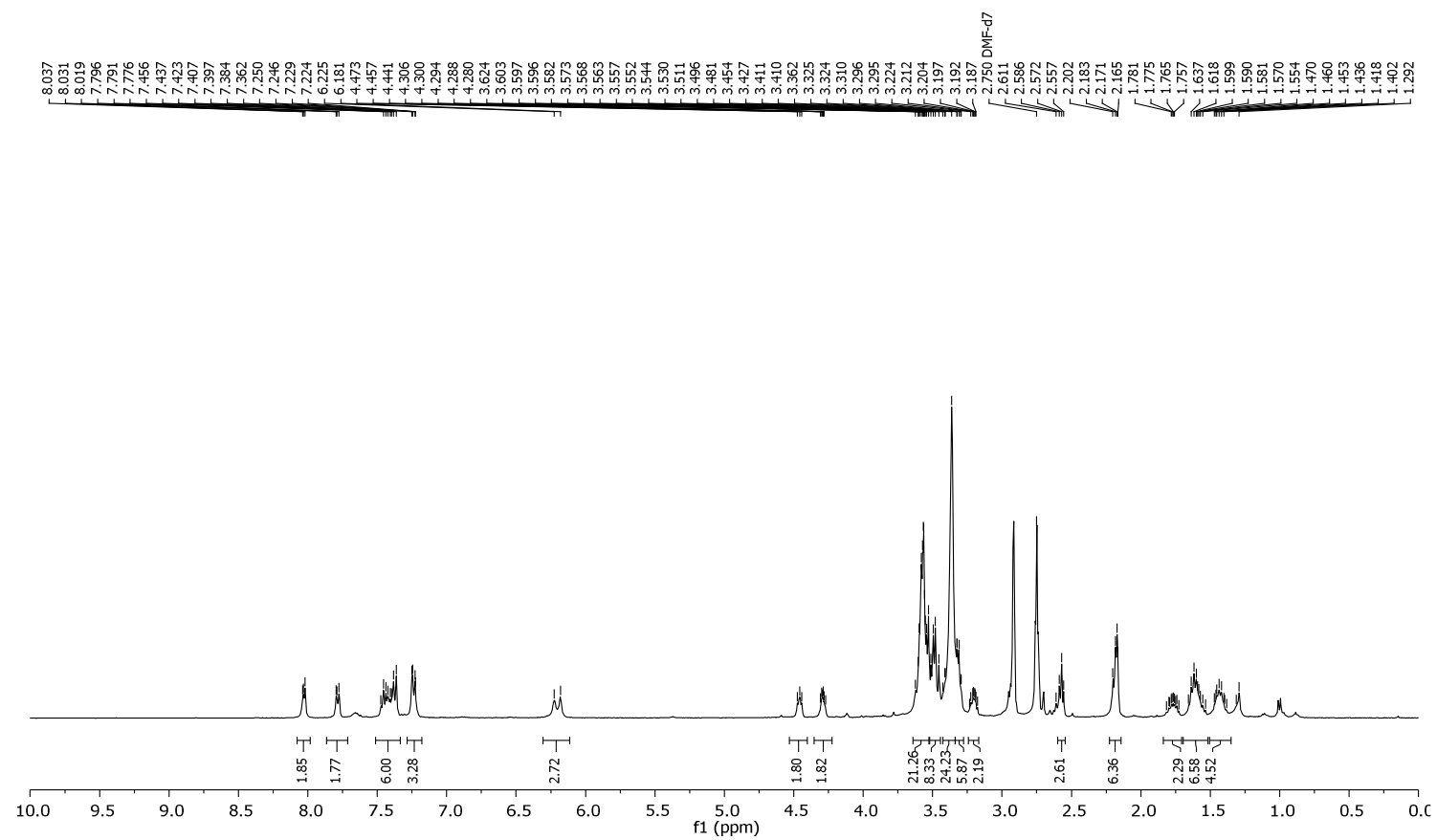

S10. ${ }^{13} \mathrm{C}$ NMR (101 MHz, DMF- $\left.d_{7}\right) \delta(\mathrm{ppm})$ of compound 3:
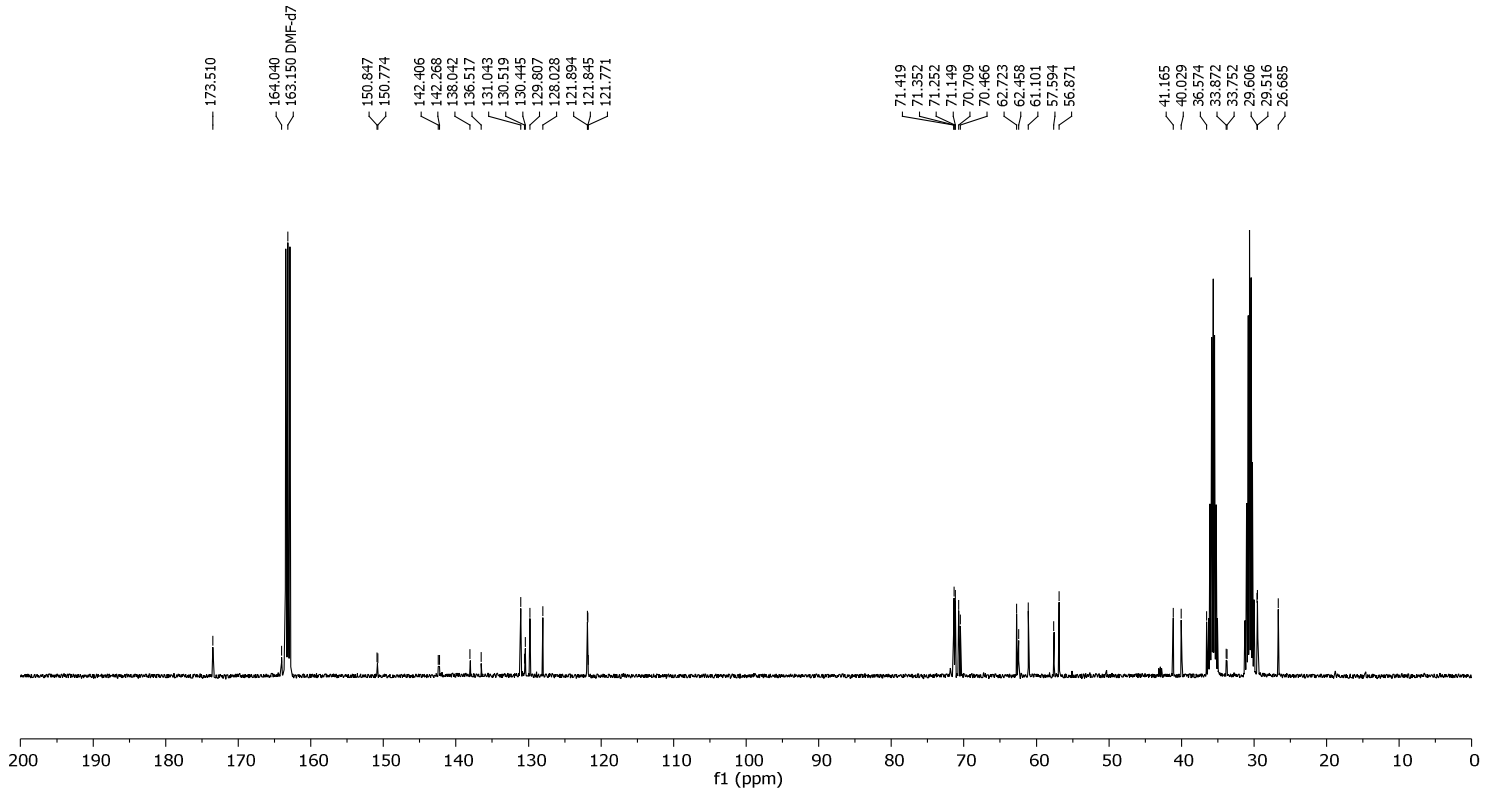
S11. ${ }^{31} \mathrm{P}$ NMR $\left(162 \mathrm{MHz}\right.$, acetone- $\left.d_{6}\right) \delta(\mathrm{ppm})$ of compound 3:
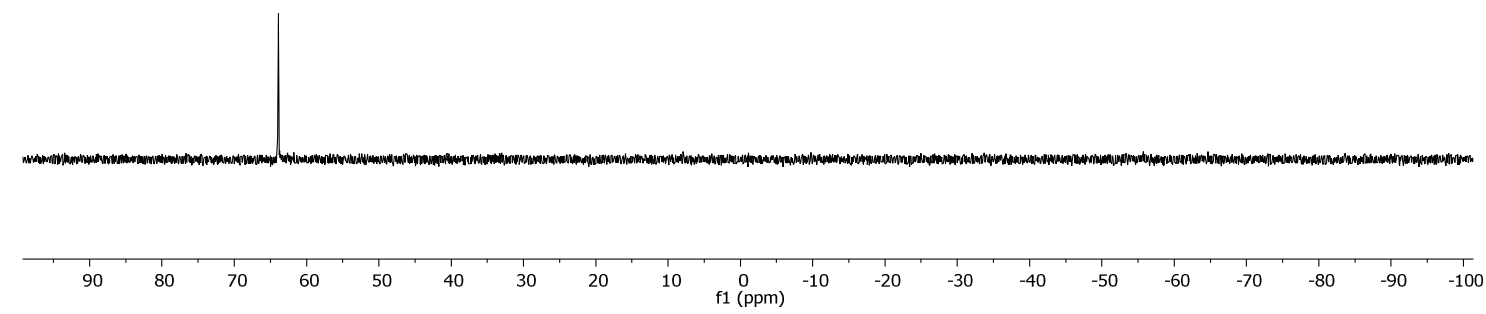

S12. IR (ATR) $v_{\max }\left(\mathrm{cm}^{-1}\right)$ of compound 3:

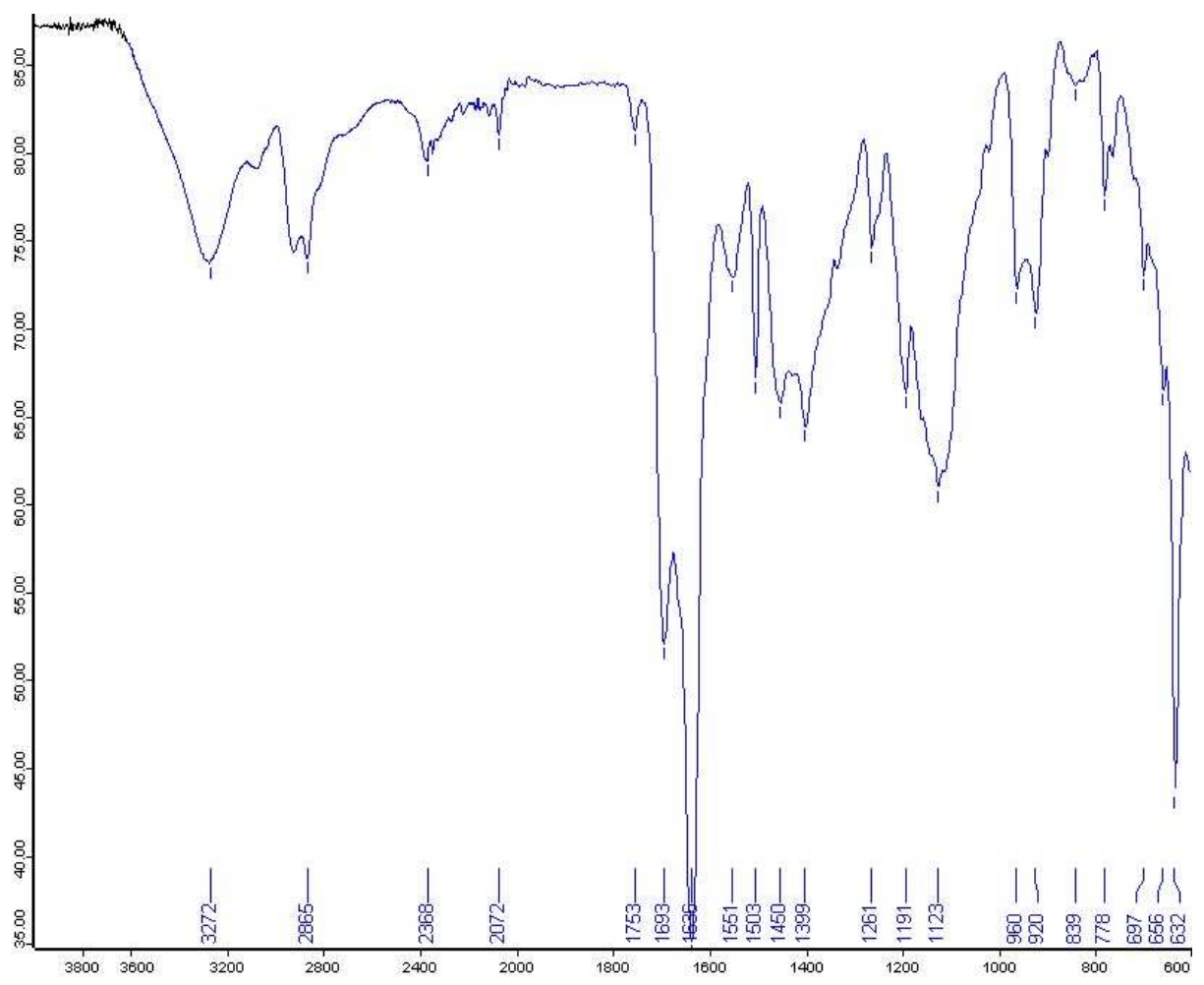




\section{Compound G1-biotin}

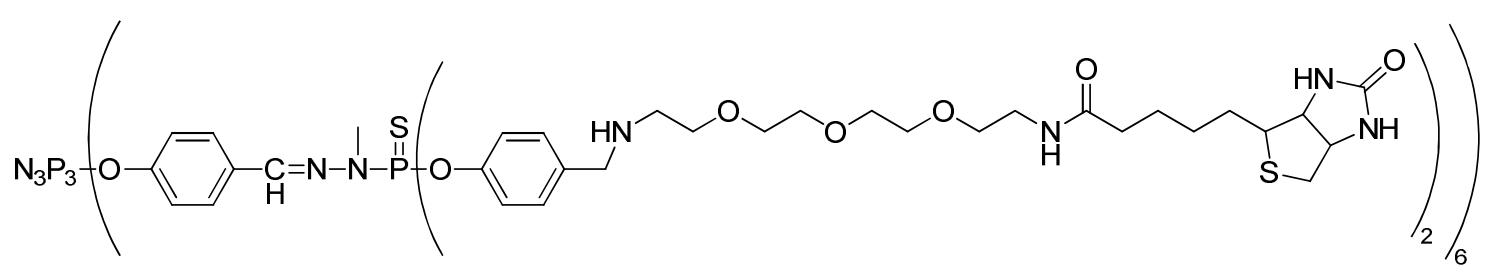

S13. ${ }^{1} \mathrm{H}$ NMR $\left(250 \mathrm{MHz}, \mathrm{DMF}-d_{7}\right) \delta(\mathrm{ppm})$ of imine precursor of G1-biotin:

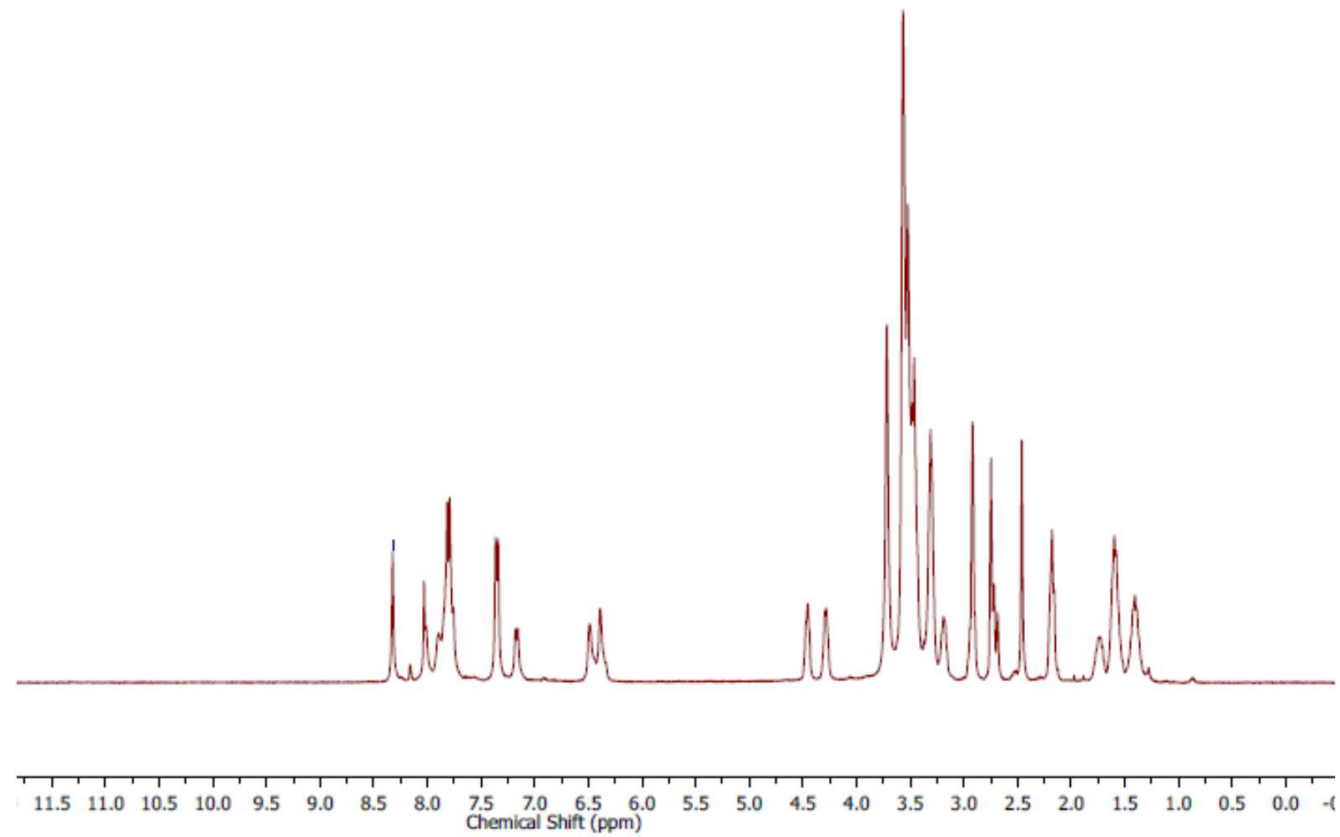

S14. ${ }^{1} \mathrm{H}$ NMR (400 MHz, DMF- $\left.d_{7}\right) \delta$ (ppm) of compound G1-biotin:

䓂

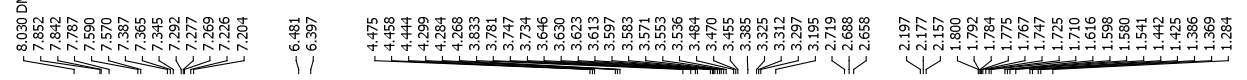

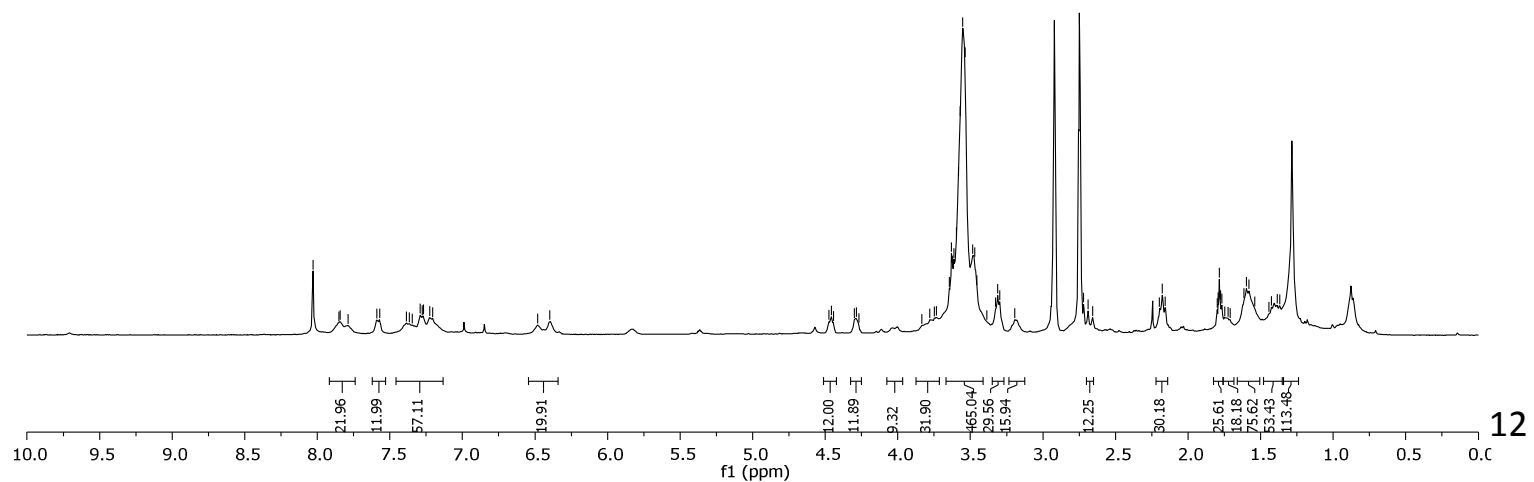


S15. ${ }^{13} \mathrm{C}$ NMR $\left(101 \mathrm{MHz}, \mathrm{DMF}-d_{7}\right) \delta(\mathrm{ppm})$ of compound G1-biotin:

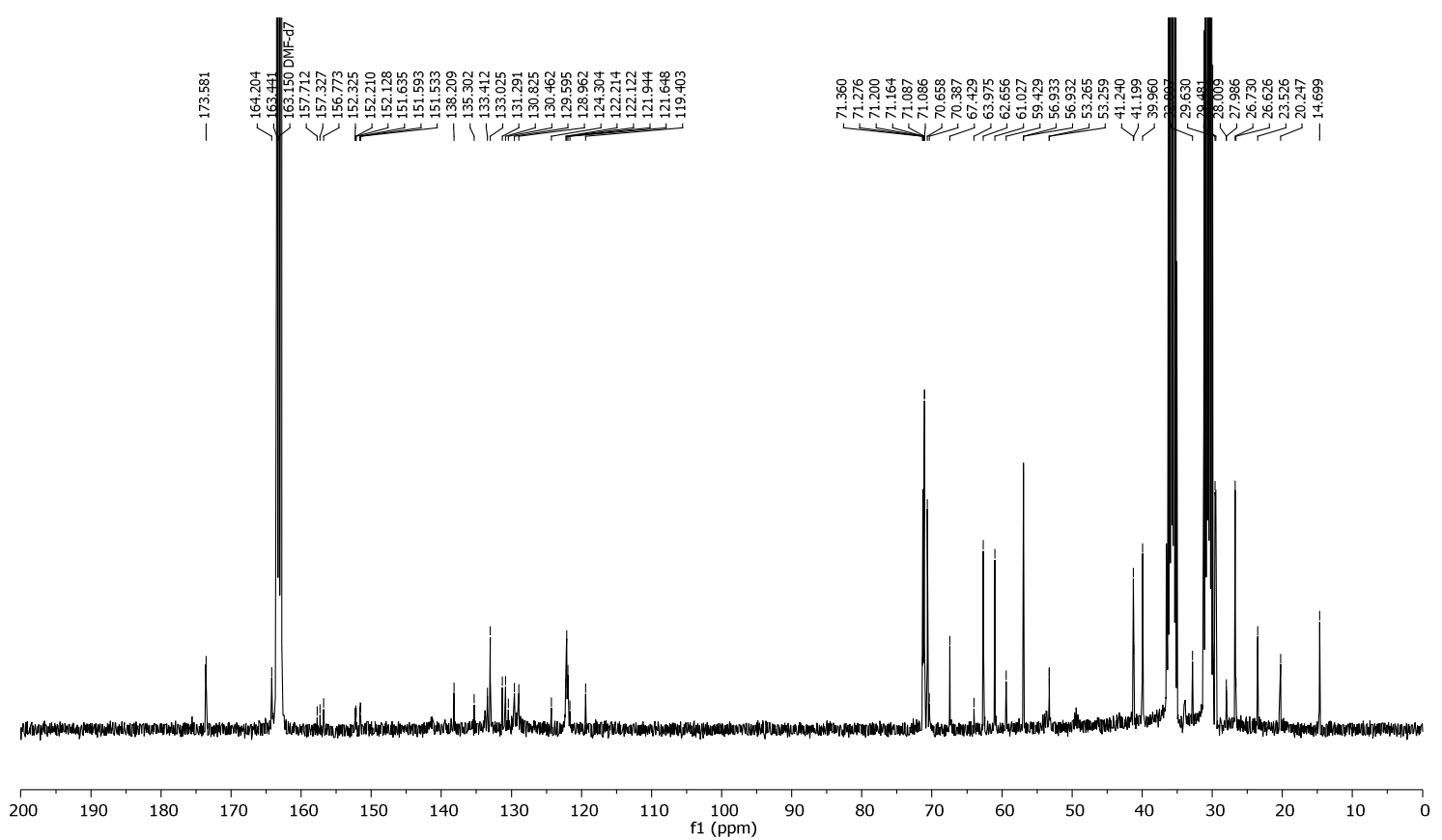

S16. ${ }^{31}$ P NMR $\left(162 \mathrm{MHz}\right.$, DMF- $\left.d_{7}\right) \delta(\mathrm{ppm})$ of compound G1-biotin:

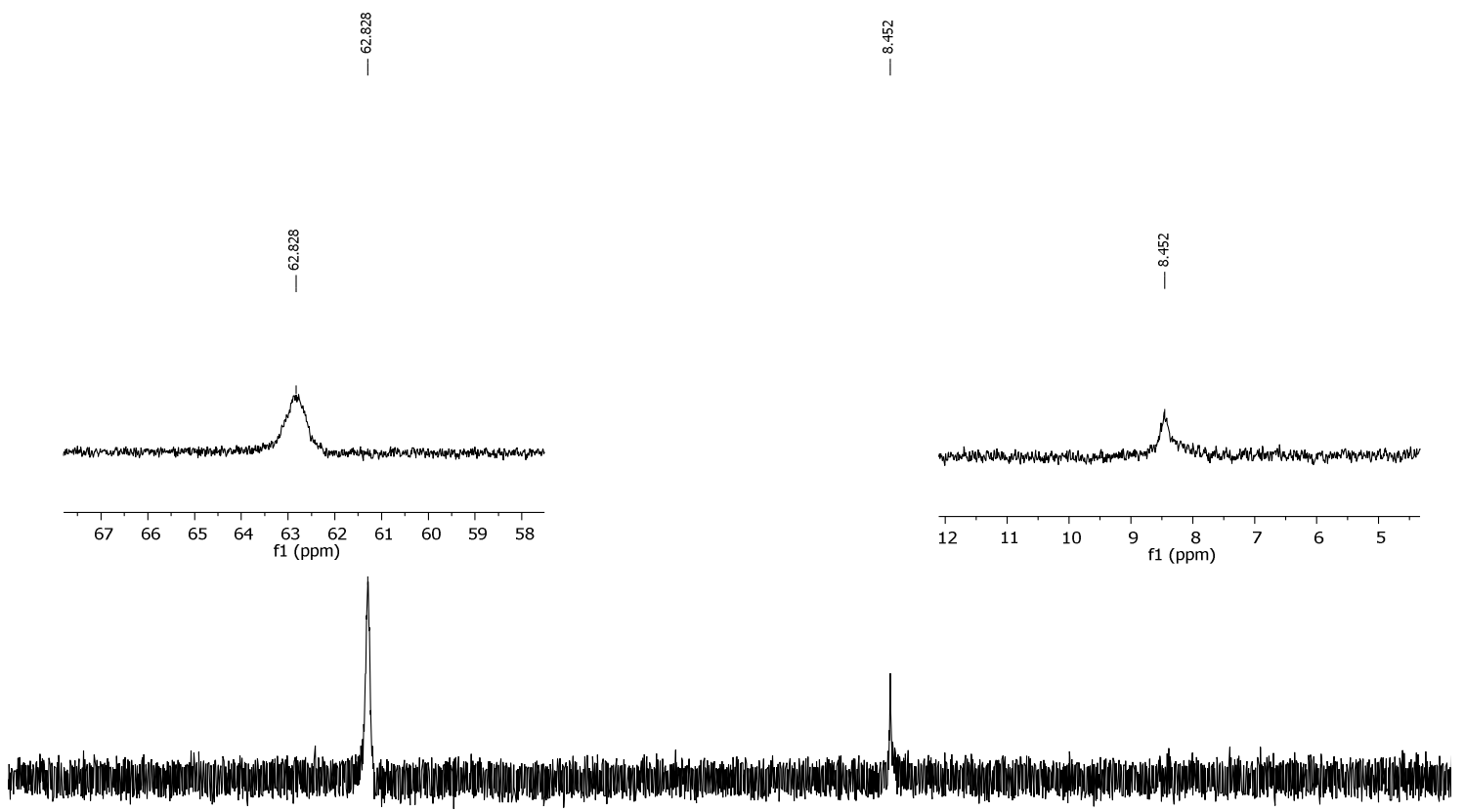

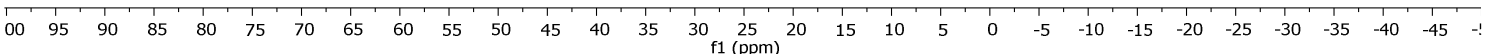


S17. IR (ATR) $v_{\max }\left(\mathrm{cm}^{-1}\right)$ of compound G1-biotin:

Servei d'Anàlisi Química

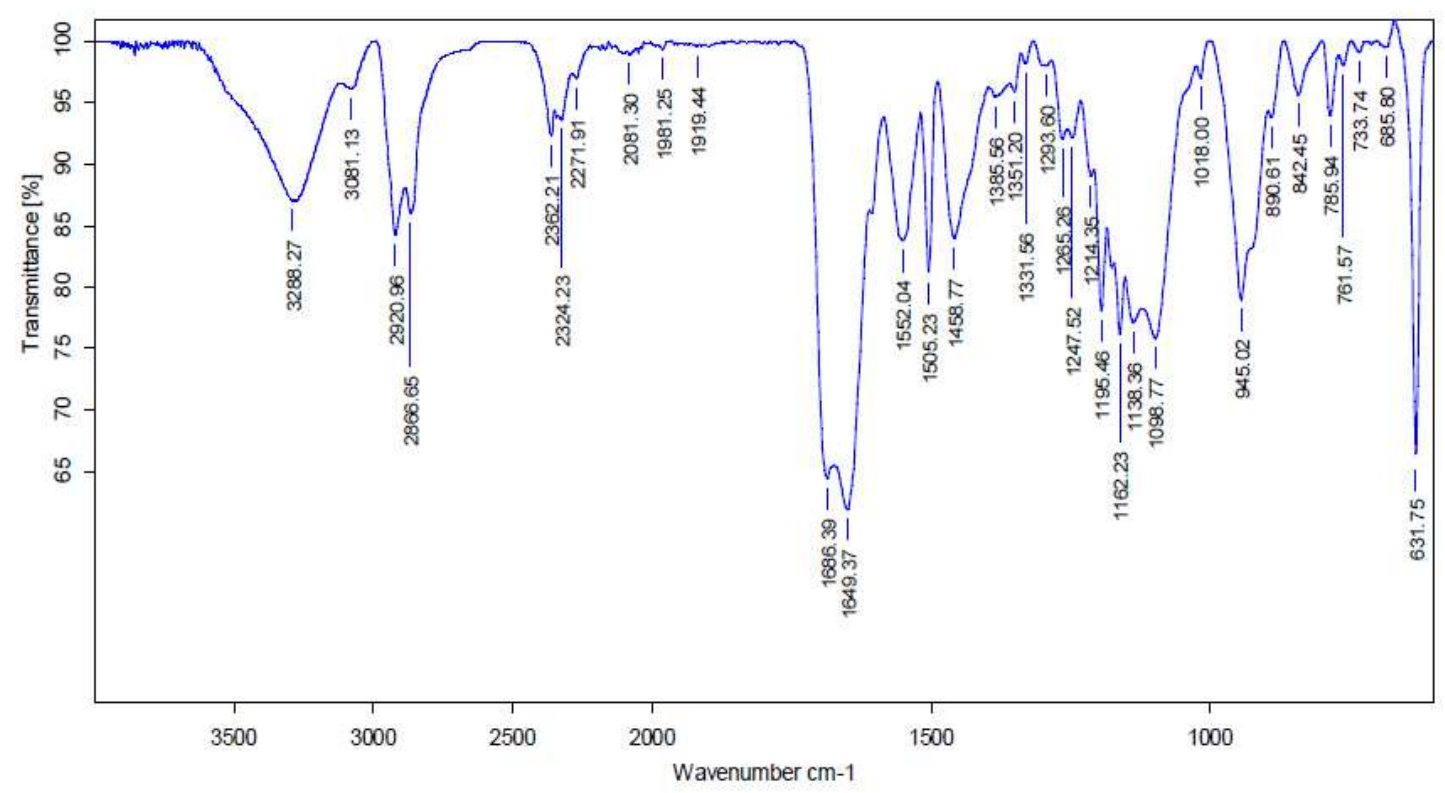

\begin{tabular}{|l|l|}
\hline LVP-GC1-NH-PEG3-Biotina & Laura Vidal \\
D:IUSUARIS_IRINORDI_SLVVP-GC1-NH-PEG3-Biotina.0 & $11 / 06 / 2018$ \\
\cline { 2 - 2 } & MKII Golden Gate \\
\hline
\end{tabular}




\section{Compound G4-biotin}

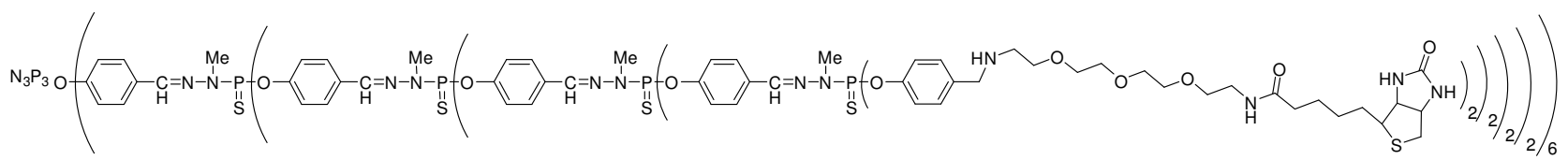

S18. ${ }^{1} \mathrm{H}$ NMR (250 MHz, DMF- $\left.\mathrm{d}_{7}\right) \delta(\mathrm{ppm})$ of imine precursor of G4-biotin:

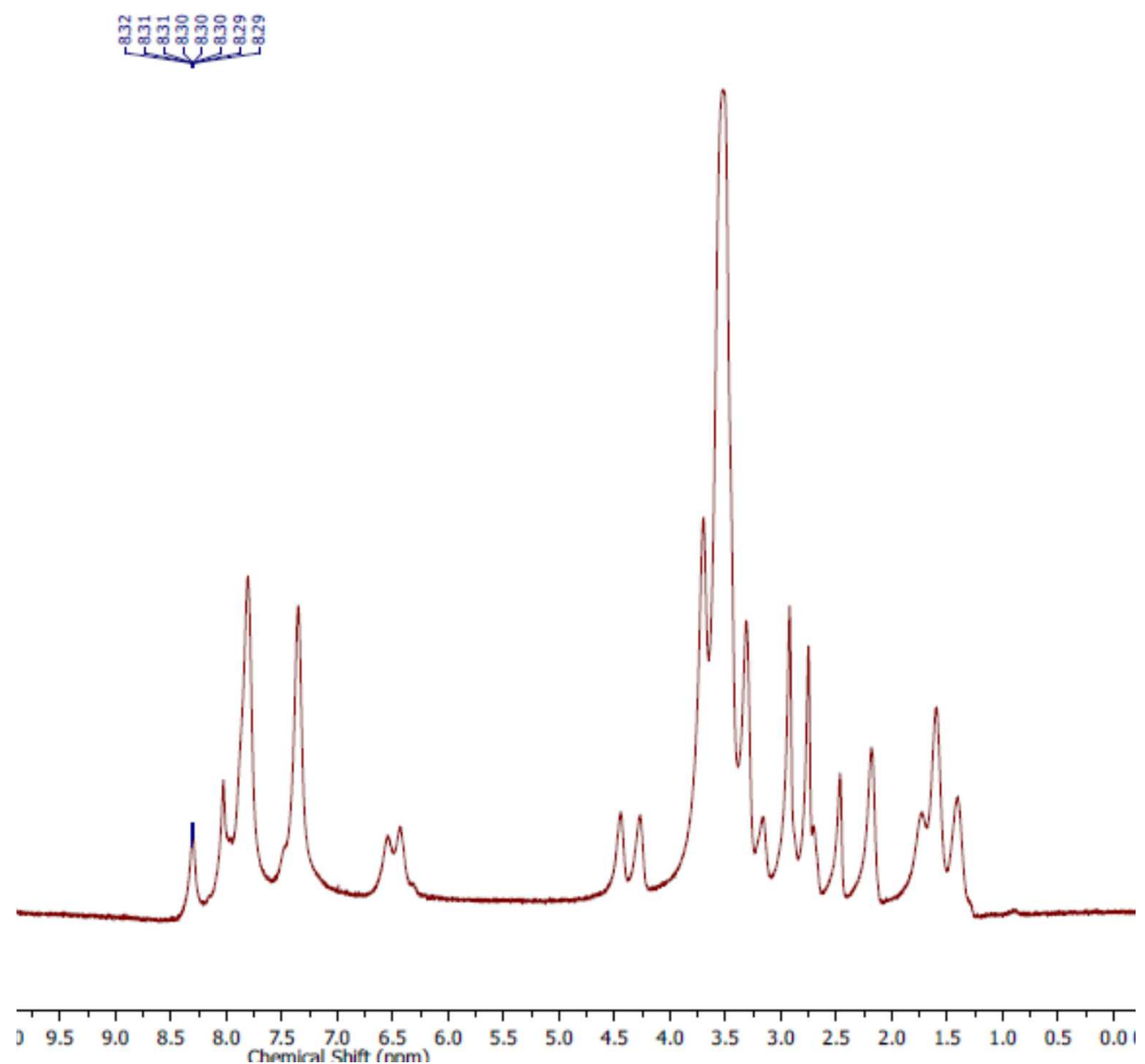


S19. ${ }^{1} \mathrm{H}$ NMR (400 MHz, DMF-d 7 ) $\delta$ (ppm) of compound G4-biotin:

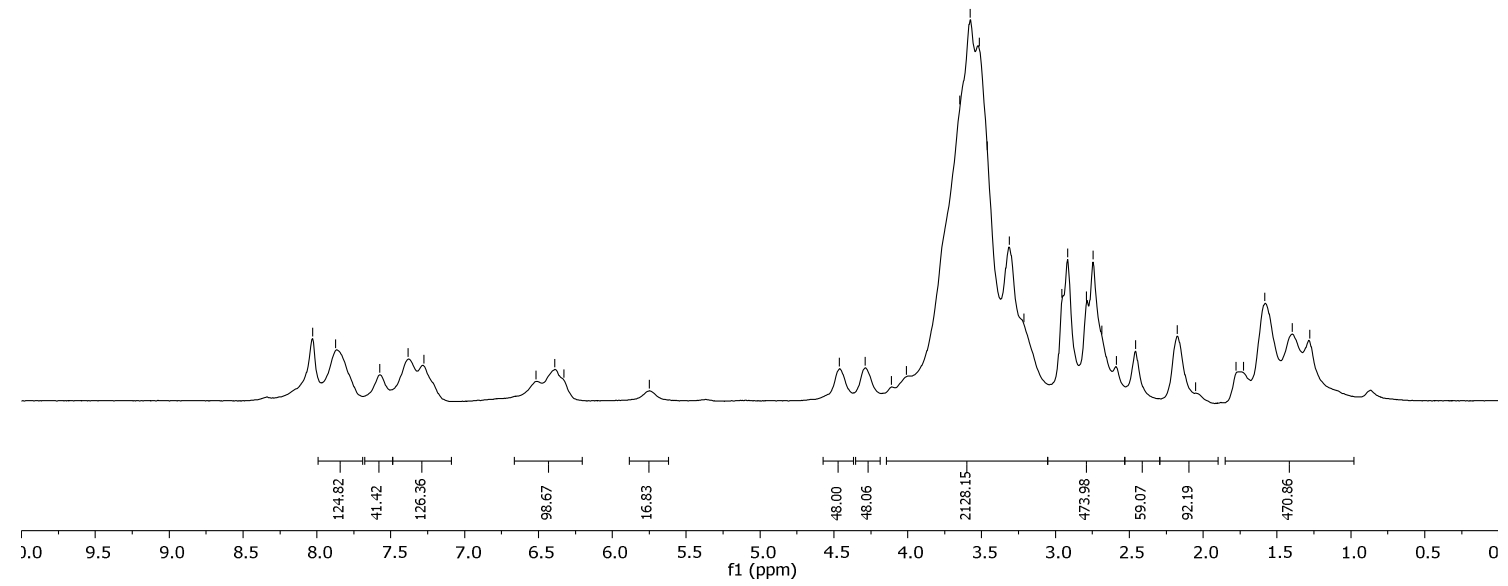

S20. ${ }^{13} \mathrm{C}$ NMR (101 MHz, DMF- $\left.\mathrm{d}_{7}\right) \delta(\mathrm{ppm})$ of compound $\mathbf{5}-\mathrm{G}_{4}$ :

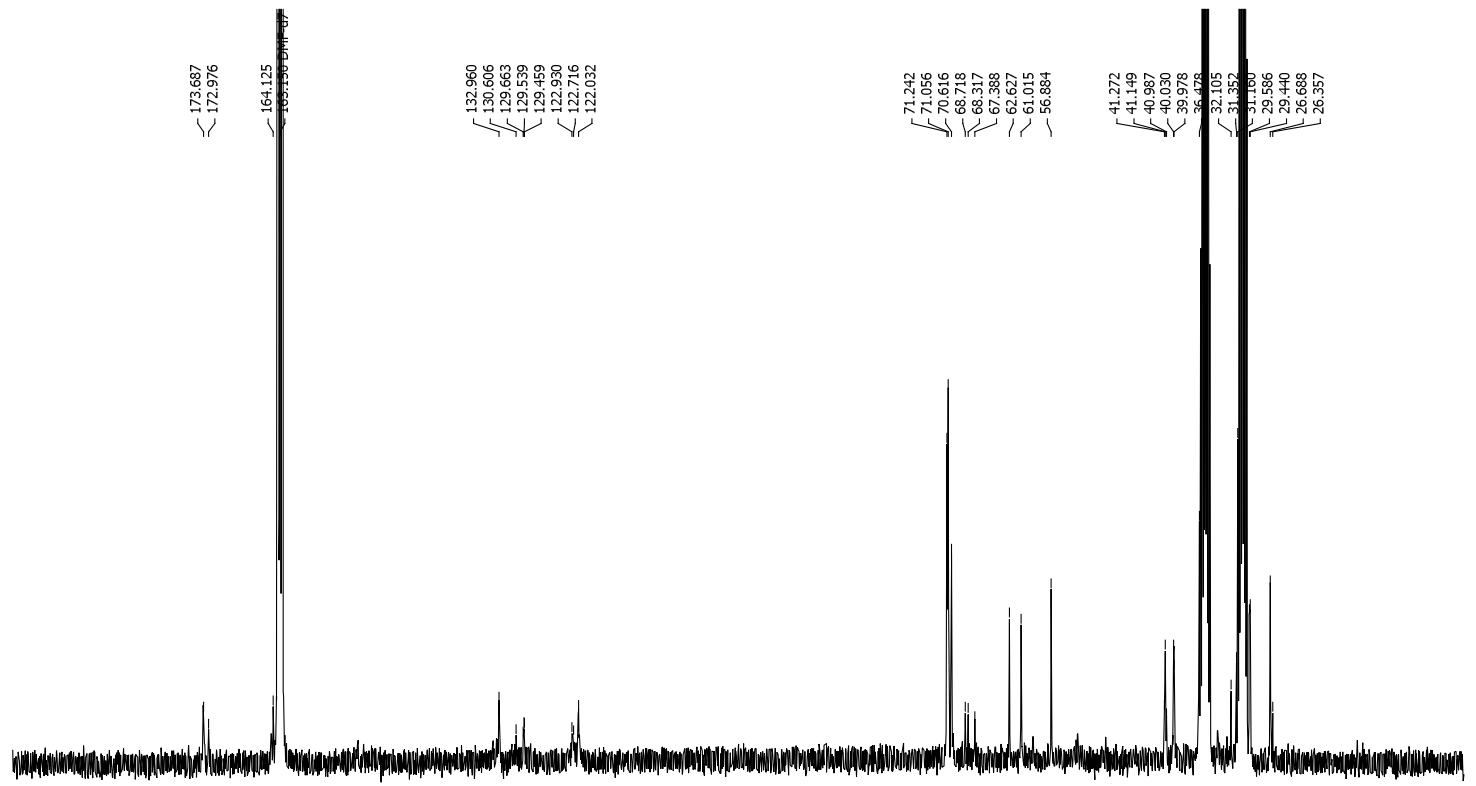

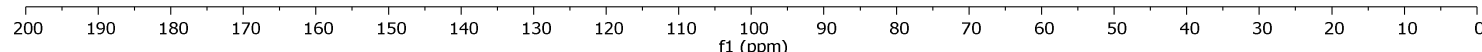


S21. ${ }^{31} \mathrm{P}$ NMR $\left(162 \mathrm{MHz}, \mathrm{DMF}-\mathrm{d}_{7}\right) \delta(\mathrm{ppm})$ of compound $\mathbf{5}-\mathbf{G}_{4}$ :

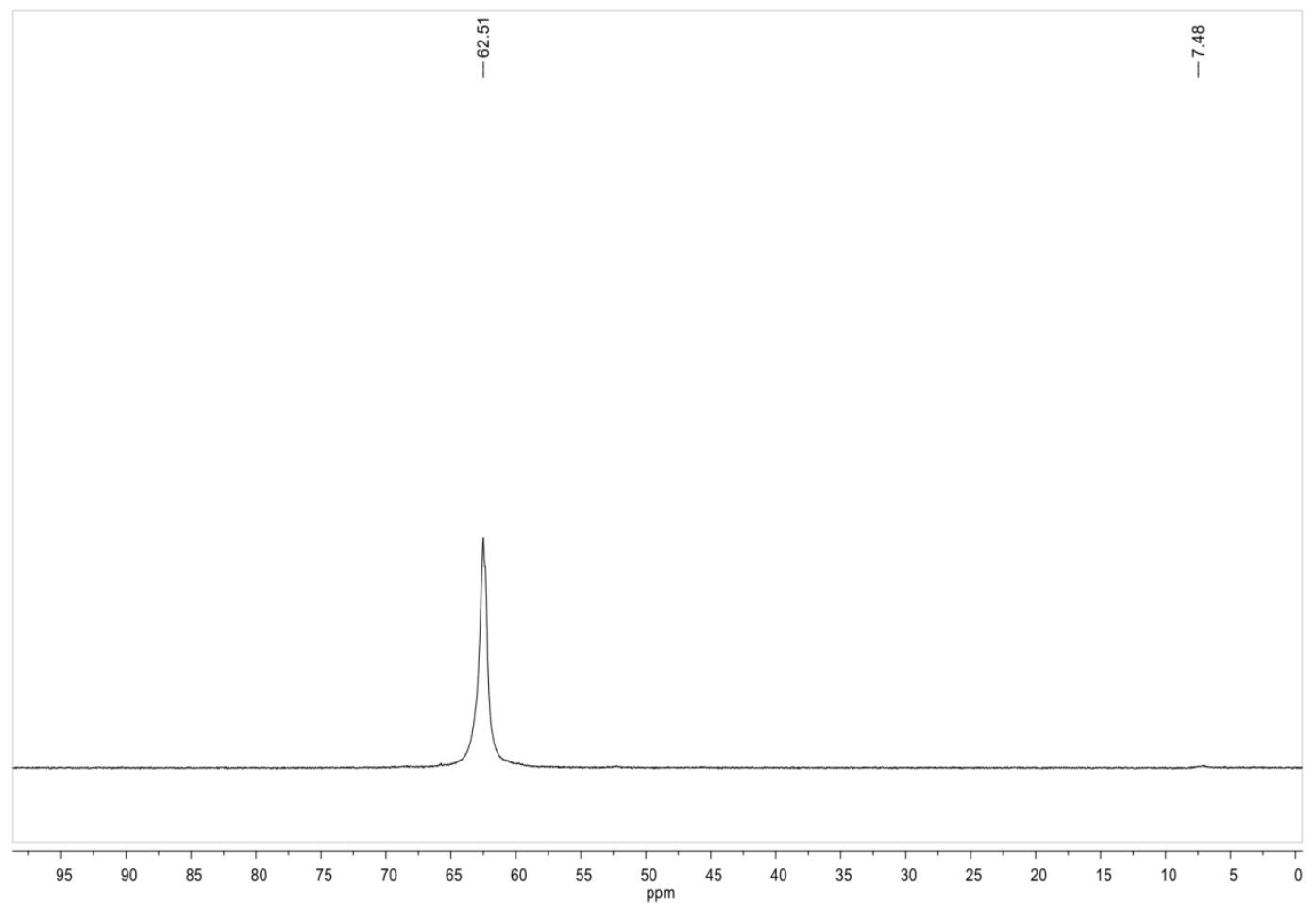

S22. IR (ATR) $v_{\max }\left(\mathrm{cm}^{-1}\right)$ of compound $\mathbf{5}-\mathbf{G}_{4}$ :

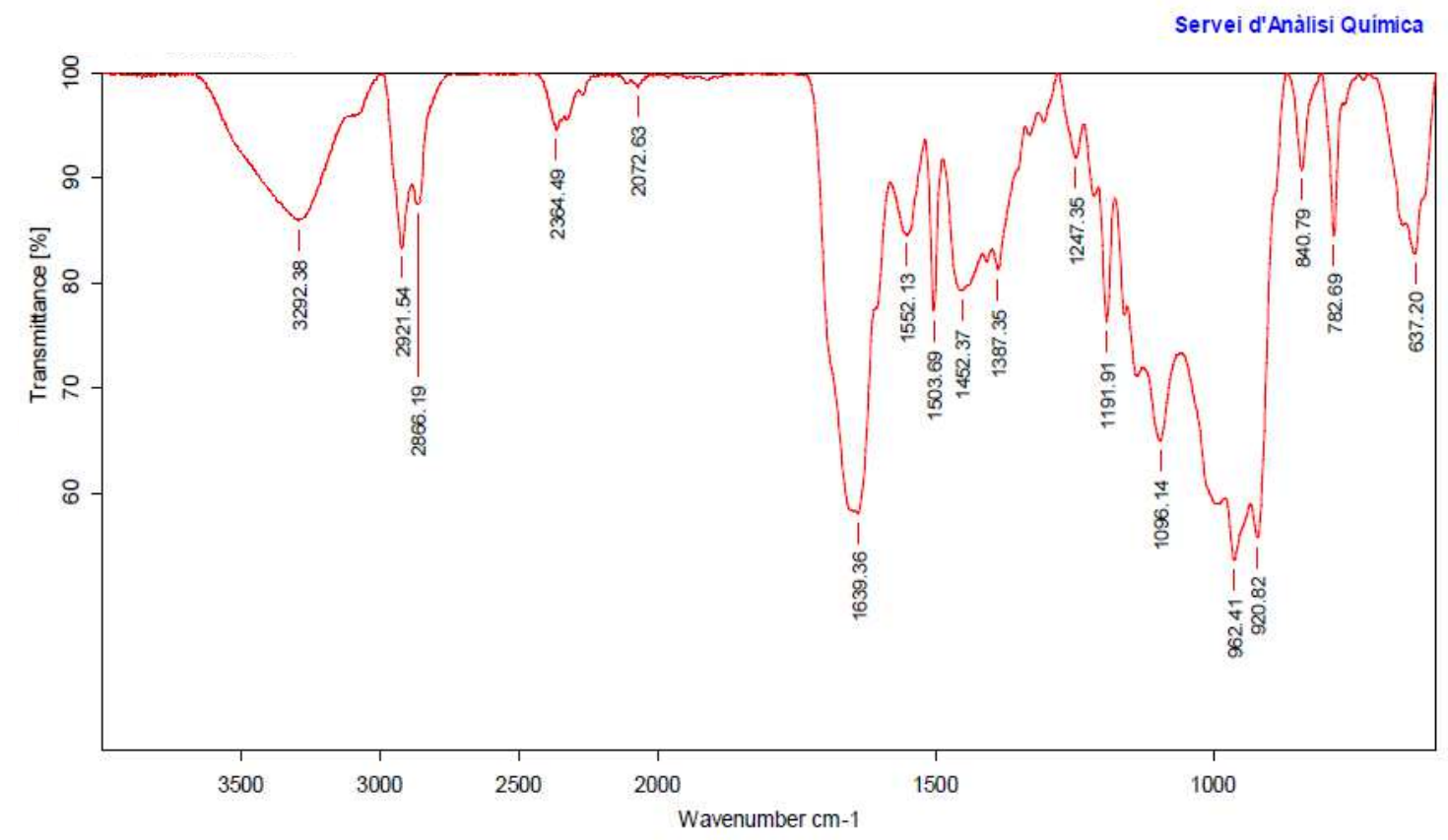

\begin{tabular}{|l|l|}
\hline LVP-GC4-NH-PEG3-Biotina & Laura Vidal \\
\cline { 2 - 2 } D:IUSUARIS_IRIJORDI_SILVP-GC4-NH-PEG3-Biotina.0 & $11 / 06 / 2018$ \\
\cline { 2 - 2 } & MKII Golden Gate \\
\hline D:IUSUARIS_IRIJORDI_SILVP-GC4-NH-PEG3-Biotina.0 & $11 / 06 / 2018$ \\
\cline { 2 - 2 } & MKII Golden Gate \\
\hline
\end{tabular}


S23. AFM images of aggregates of compound $\mathbf{5}-\mathbf{G}_{\mathbf{4}}$ in $\mathrm{MeOH}(1 \mathrm{mg} / \mathrm{mL})$ on mica surface. Topographic AFM image of a $20 \times 20 \mu \mathrm{m}^{2}$ area of the sample. Images and profiles were taken using PicoScan software (Molecular Imaging, USA). Mica slides were used as substrates after sonication in acetone for $5 \mathrm{~min}$ and subsequent drying under $\mathrm{N}_{2}$ flow.

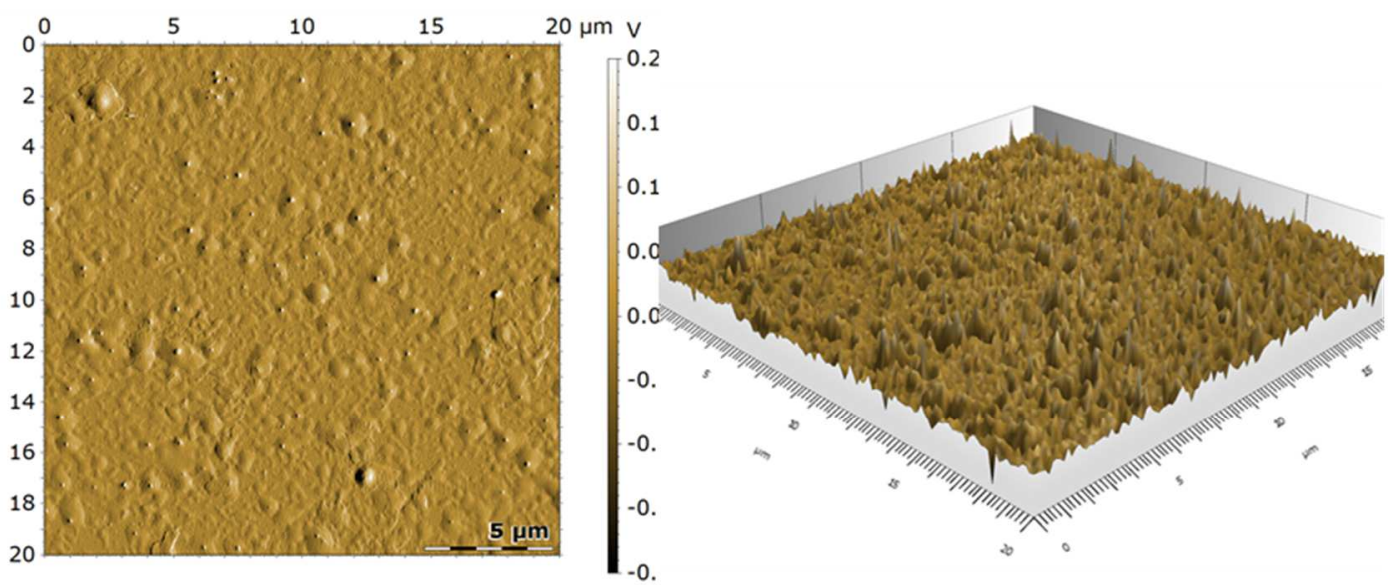

S24. TEM image of compound $\mathbf{5}-\mathbf{G}_{\mathbf{4}}$ using uranyl acetate as negative stain. Diameter distribution histogram is also indicated. Nanoparticle sizes were determined by measuring 419 particles using ImageJ (Fiji) program, and from them the average diameter value was calculated.

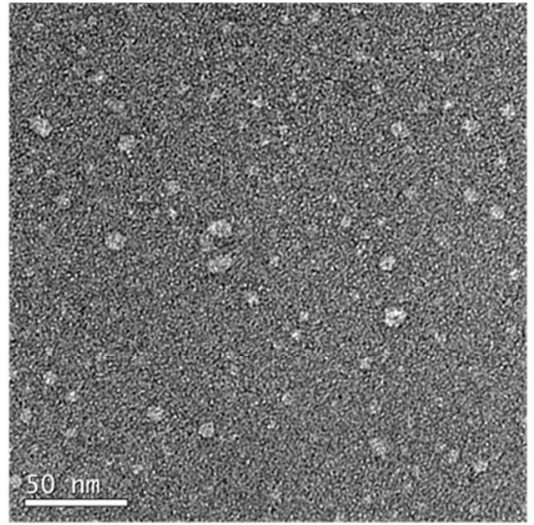

a)

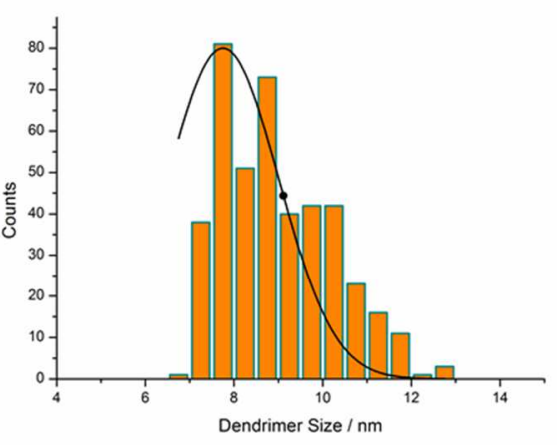

b) 


\section{S25. Preparation and assembly of the lateral flow strips}

In order to absorb all the components on the nitrocellulose strips, a Lateral Flow Reagent Dispenser from Claremont Bio (Upland, CA) combined with the KDS Legato $^{\mathrm{TM}} 200$ series syringe pump fromKD Scientific Inc. (Holliston, MA) was used to obtain a straight and well define line.

Before starting, the canal of the dispenser was cleaned with $5 \mathrm{~mL}$ of water, methanol, water and air, respectively. $150 \mu \mathrm{L}$ of the desired solution was taken and placed in the dispenser at a rate of $38 \mu \mathrm{L} \mathrm{min}{ }^{-1}$. The solution was run through the channel until the end of the nitrocellulose, forming a perfect, defined line. The dispenser was cleaned again and the strip is left to dry for approximately 30 minutes.

Once the dendrimer was deposited on the nitrocellulose, the LFA strip was prepared by following this scheme:

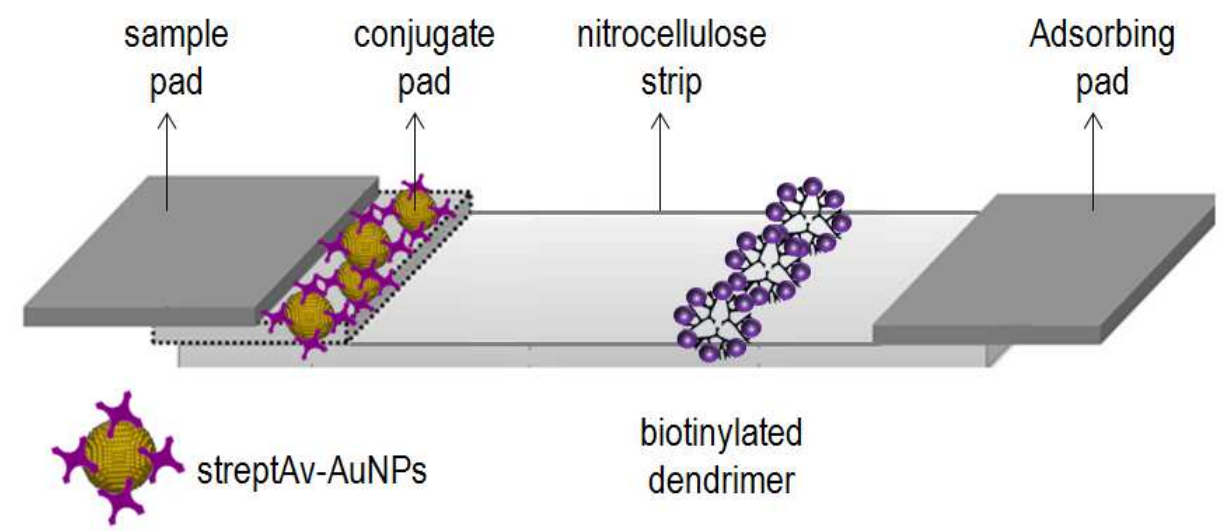

Preparation of conjugate pad: A final volume of $50 \mu \mathrm{l}$ of streptAv-AuNPs (of a concentration ranging from $3.69 \cdot 10^{-12}$ to $5.9 \cdot 10^{-11} \mathrm{~mol} \mathrm{~L}^{-1}$ ) was prepared by dilution of the commercially available InnovaCoat ${ }^{\circledR}$ GOLD $40 \mathrm{~nm}$ Streptavidin gold nano-particles (streptAv-AuNPs) (10 OD, SPR peak $530 \mathrm{~nm}$, molar extinction $8.42109 \mathrm{M}^{-1} \mathrm{~cm}^{-1}$, molar concentration $1.1810^{-9} \mathrm{~mol} \mathrm{~L}^{-1}$ ) (purchased from Innova Bios-ciences, Cambridge, UK) with the corresponding quantity conjugate buffer as solvent (2 $\mathrm{mmol} \cdot \mathrm{L}^{-1}$ borate $\mathrm{pH}=7,10 \% \mathrm{w} / \mathrm{v}$ sucrose) was dispensed in the glass fiber conjugate pad. Then it was dried for approximately 2 hours at RT.

Finally, the strips were assembled in the usual way on the adhesive backing card.

Once the strip is prepared, $100 \mu \mathrm{L}$ of running buffer $\left(0.01 \mathrm{~mol} \mathrm{~L}^{-1}\right.$ phosphate buffer $\mathrm{pH}$ $7.4,1 \%$ BSA, $0.05 \%$ Tween 20 ) were deposited in the sample pad. Further aliquots of $50 \mu \mathrm{L}$ running buffer was added until the conjugate pad was completely white, indicating the complete remove of the streptAv-AuNPs. A well-defined line was thus 
observed on the biotinylated dendrimer line due to the interaction of the gold NPs modified with streptavidin and the biotinylated dendrimer deposited on the control line.

\section{S26. Readout of the intensity by the ImageJ software}

The software can measure and quantify the intensity of the colour of the strip lines. The signal can then be plotted in order to relate the color intensity with the concentration.

For this process, a picture of the strips is taken with good lighting. With this program the parameters of contrast, brightness, etc. of the photo are adjusted until the red line looks clear.

The areas of the nitrocellulose with the red line are selected and the intensity is measured along it. As a result, the program gives a graph showing the intensity of the colour versus the position of the picture. With the same program, these peaks are integrated giving the area of the intensity of the colour in the control line. 


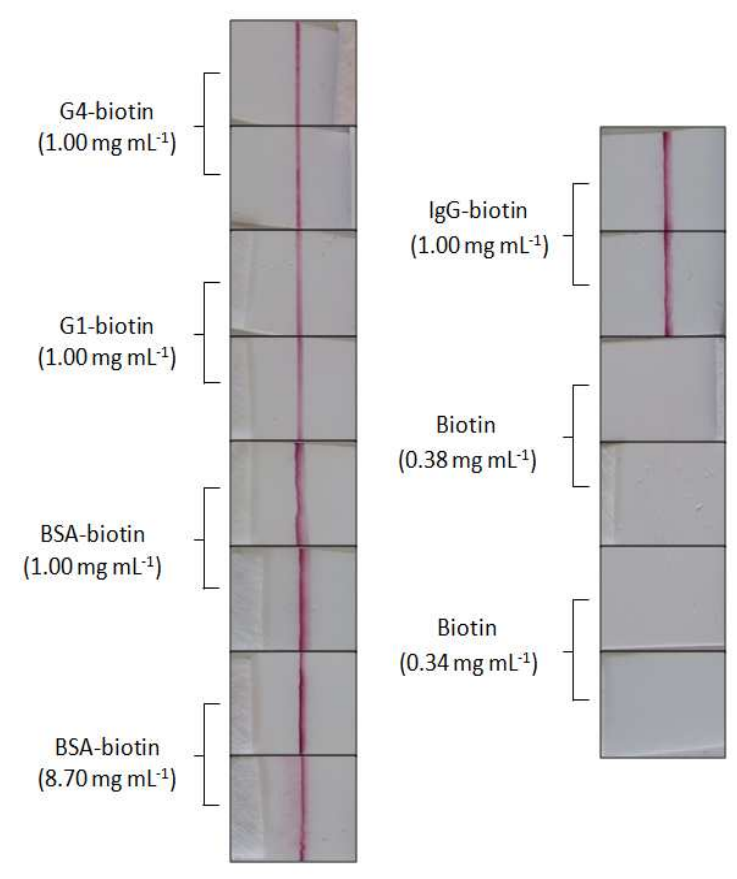

\begin{tabular}{|c|c|c|}
\hline \multirow{2}{*}{$\begin{array}{l}\text { Biotinylated } \\
\text { compound } \\
\left(\mathrm{mg} \mathrm{mL}^{-1}\right)\end{array}$} & \multicolumn{2}{|c|}{ Biotin content } \\
\hline & $\mathrm{mg} \mathrm{mL}^{-1}$ & $\mu \mathrm{mol} \mathrm{mL} L^{-1}$ \\
\hline $\begin{array}{c}\text { G4-biotin } \\
\left(1.00 \mathrm{mg} \mathrm{mL}^{-1}\right)\end{array}$ & 0.338 & 1.38 \\
\hline $\begin{array}{c}\text { G1-biotin } \\
\left(1.00 \mathrm{mg} \mathrm{mL}^{-1}\right)\end{array}$ & 0.381 & 1.56 \\
\hline $\begin{array}{c}\text { BSA-biotin } \\
\left(1.00 \mathrm{mg} \mathrm{mL}^{-1}\right)\end{array}$ & 0.041 & 0.17 \\
\hline $\begin{array}{c}\text { BSA-biotin } \\
\left(8.70 \mathrm{mg} \mathrm{mL}^{-1}\right)\end{array}$ & 0.359 & 1.47 \\
\hline $\begin{array}{c}\text { IgG-biotin } \\
\left(1.00 \mathrm{mg} \mathrm{mL}^{-1}\right)\end{array}$ & $\begin{array}{c}\text { not provided by } \\
\text { the supplier }\end{array}$ & $\begin{array}{l}\text { not provided } \\
\text { by the supplier }\end{array}$ \\
\hline $\begin{array}{c}\text { Biotin } \\
\left(0.38 \mathrm{mg} \mathrm{mL}^{-1}\right)\end{array}$ & 0.381 & 1.56 \\
\hline $\begin{array}{c}\text { Biotin } \\
\left(0.34 \mathrm{mg} \mathrm{mL}^{-1}\right)\end{array}$ & 0.338 & 1.38 \\
\hline
\end{tabular}

Figure S27. Left: Images of strips of LFA tests showing interaction between different biotinylated macromolecules (G1-biotin, G4-biotin, BSA-biotin and IgG-biotin) and free biotin with $5.9010^{-11} \mathrm{~mol} \mathrm{~L}^{-1}$ streptAv-AuNPs. For each experiment, $\mathrm{n}=2$. Right.

Table contents: moles of dendrimers and biotin moieties in $\mathrm{mg} \mathrm{mL}^{-1}$ and of $\mu \mathrm{mol} \mathrm{mL} \mathrm{m}^{-1}$. 

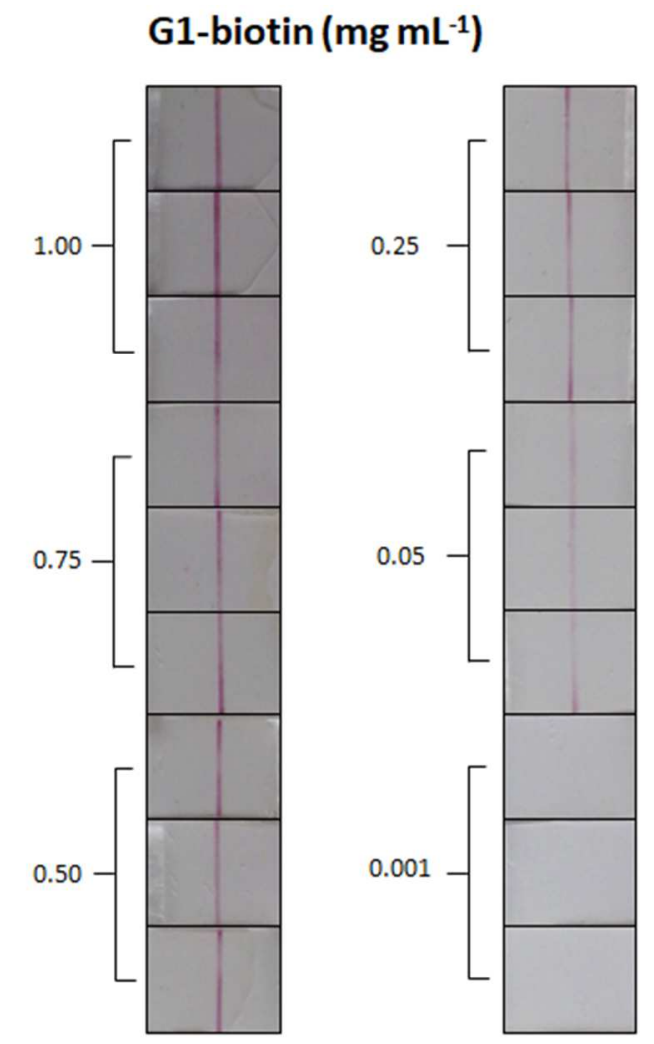

\begin{tabular}{|c|c|c|c|}
\hline \multicolumn{2}{|c|}{ G1-biotin } & \multicolumn{2}{|c|}{$\begin{array}{c}\text { Biotin molecule } \\
\text { content }\end{array}$} \\
\hline $\mathrm{mg} \mathrm{mL}^{-1}$ & $\mu \mathrm{mol} \mathrm{mL}^{-1}$ & $\mathrm{mg} \mathrm{mL}^{-1}$ & $\mu \mathrm{mol} \mathrm{mL^{-1 }}$ \\
\hline 1.00 & 0.13 & 0.380 & 1.560 \\
\hline 0.75 & $9.75 \cdot 10^{-2}$ & 0.286 & 1.17 \\
\hline 0.50 & $6.51 \cdot 10^{-2}$ & 0.191 & 0.781 \\
\hline 0.25 & $3.23 \cdot 10^{-2}$ & $9.50 \cdot 10^{-2}$ & 0.388 \\
\hline 0.05 & $6.50 \cdot 10^{-3}$ & $1.90 \cdot 10^{-2}$ & $7.80 \cdot 10^{-2}$ \\
\hline 0.001 & $1.30 \cdot 10^{-4}$ & $3.81 \cdot 10^{-4}$ & $1.56 \cdot 10^{-3}$ \\
\hline
\end{tabular}

Figure S28. Left. LFA images using different concentration of dispensed G1-biotin dendrimers (9:1, water:DMF) as control line, after interaction with $5.9010^{-11} \mathrm{~mol} \mathrm{~L}^{-1}$ streptAv-AuNPs. $n=3$. Right. Table contents: moles of dendrimers and biotin moieties in $\mathrm{mg} \mathrm{mL}^{-1}$ and of $\mu \mathrm{mol} \mathrm{mL}^{-1}$ solutions. 


\section{G1-biotin ( $\mathrm{mg} \mathrm{mL}^{-1}$ )}
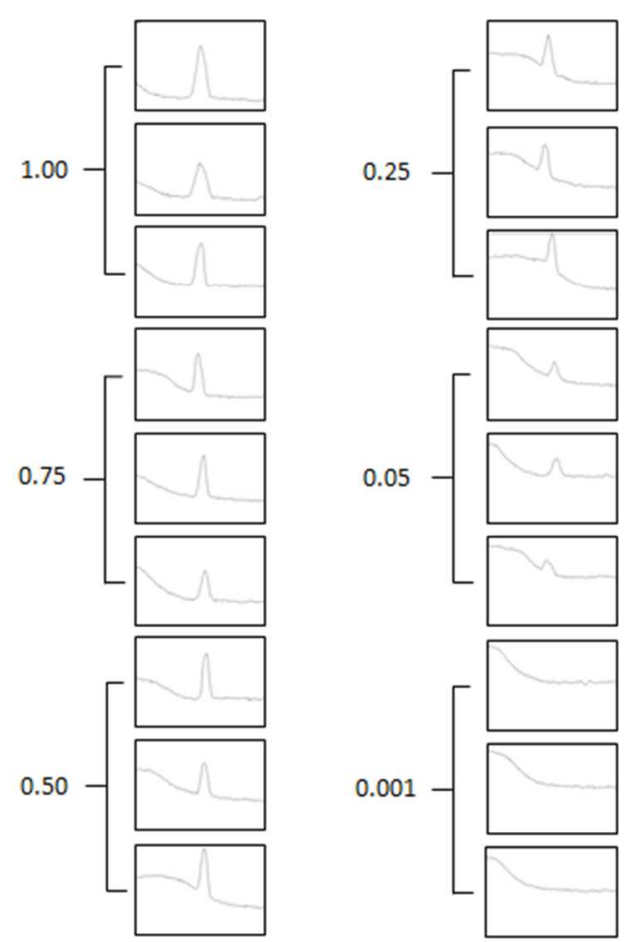

\begin{tabular}{|c|c|c|c|}
\hline \multicolumn{2}{|c|}{ G1-biotin } & \multicolumn{2}{|c|}{$\begin{array}{c}\text { Biotin molecule } \\
\text { content }\end{array}$} \\
\hline $\mathrm{mg} \mathrm{mL}^{-1}$ & $\mu \mathrm{mol} \mathrm{mL} \mathrm{L}^{-1}$ & $\mathrm{mg} \mathrm{mL}^{-1}$ & $\mu \mathrm{mol} \mathrm{mL} L^{-1}$ \\
\hline 1.00 & 0.13 & 0.380 & 1.560 \\
\hline 0.75 & $9.75 \cdot 10^{-2}$ & 0.286 & 1.17 \\
\hline 0.50 & $6.51 \cdot 10^{-2}$ & 0.191 & 0.781 \\
\hline 0.25 & $3.23 \cdot 10^{-2}$ & $9.50 \cdot 10^{-2}$ & 0.388 \\
\hline 0.05 & $6.50 \cdot 10^{-3}$ & $1.90 \cdot 10^{-2}$ & $7.80 \cdot 10^{-2}$ \\
\hline 0.001 & $1.30 \cdot 10^{-4}$ & $3.81 \cdot 10^{-4}$ & $1.56 \cdot 10^{-3}$ \\
\hline
\end{tabular}

Figure S29. Left. Peaks obtained with the software ImageJ using different concentration of dispensed G1-biotin dendrimers (9:1, water:DMF) as control line, after interaction with $5.9010^{-11} \mathrm{~mol} \mathrm{~L}^{-1}$ streptAv-AuNPs. $\mathrm{n}=3$. Right. Table contents: moles of dendrimers and biotin moieties in $\mathrm{mg} \mathrm{mL}^{-1}$ and of $\mu \mathrm{mol} \mathrm{mL} \mathrm{m}^{-1}$ solutions. 
G4-biotin ( $\left.\mathrm{mg} \mathrm{mL}^{-1}\right)$
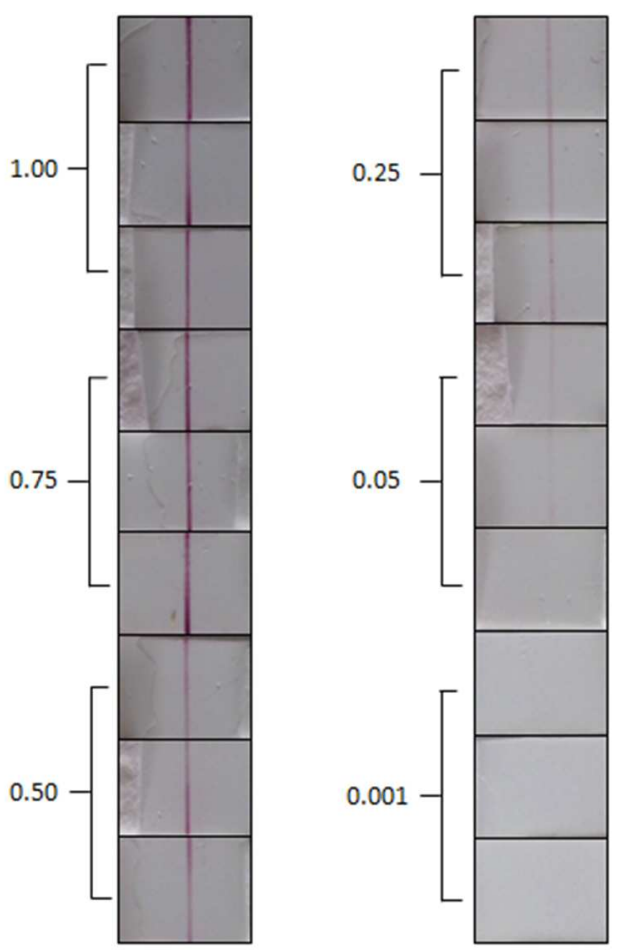

\begin{tabular}{|c|c|c|c|}
\hline \multicolumn{2}{|c|}{ G4-biotin } & \multicolumn{2}{|c|}{$\begin{array}{c}\text { Biotin molecule } \\
\text { content }\end{array}$} \\
\hline $\mathrm{mg} \mathrm{mL}^{-1}$ & $\mu \mathrm{mol} \mathrm{mL} L^{-1}$ & $\mathrm{mg} \mathrm{mL}^{-1}$ & $\mu \mathrm{mol} \mathrm{mL}^{-1}$ \\
\hline 1.00 & $1.44 \cdot 10^{-2}$ & 0.338 & 1.380 \\
\hline 0.75 & $1.08 \cdot 10^{-2}$ & 0.253 & 1.04 \\
\hline 0.50 & $7.21 \cdot 10^{-3}$ & 0.169 & 0.692 \\
\hline 0.25 & $3.58 \cdot 10^{-3}$ & $8.40 \cdot 10^{-2}$ & 0.344 \\
\hline 0.05 & $7.29 \cdot 10^{-4}$ & $1.70 \cdot 10^{-2}$ & $7.00 \cdot 10^{-2}$ \\
\hline 0.001 & $1.46 \cdot 10^{-5}$ & $3.40 \cdot 10^{-4}$ & $1.40 \cdot 10^{-3}$ \\
\hline
\end{tabular}

Figure S30. Left. LFA images using different concentration of dispensed G4-biotin dendrimers (9:1, water:DMF) as control line, after interaction with $5.9010^{-11} \mathrm{~mol} \mathrm{~L}^{-1}$ streptAv-AuNPs. $n=3$. Right. Table contents: moles of dendrimers and biotin moieties

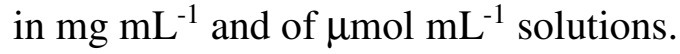


G4-biotin ( $\left.\mathrm{mg} \mathrm{mL}^{-1}\right)$
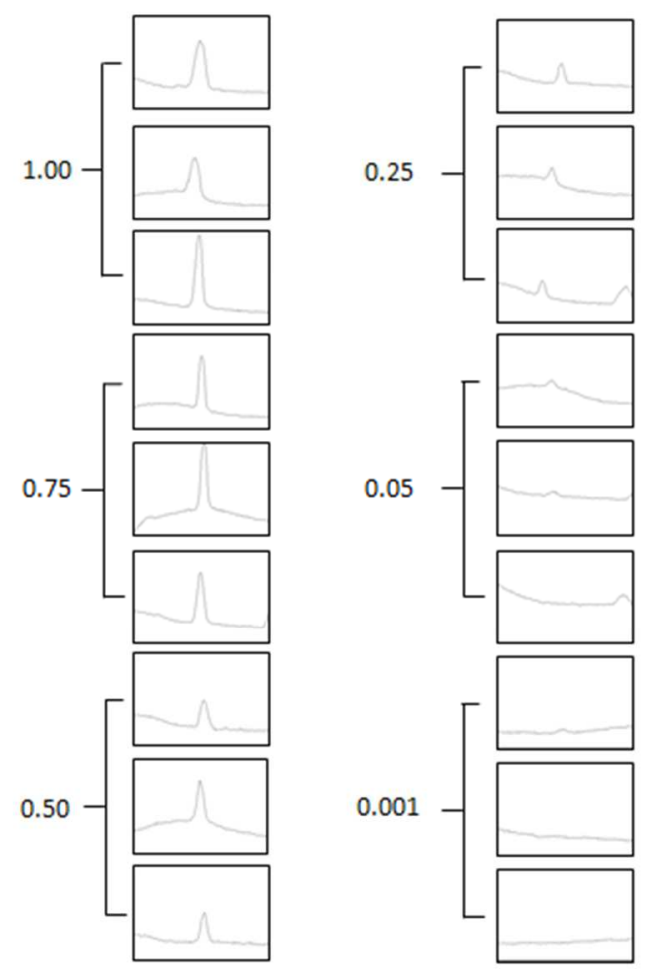

\begin{tabular}{|c|c|c|c|}
\hline \multicolumn{2}{|c|}{ G4-biotin } & \multicolumn{2}{|c|}{$\begin{array}{c}\text { Biotin molecule } \\
\text { content }\end{array}$} \\
\hline $\mathrm{mg} \mathrm{mL}^{-1}$ & $\mu \mathrm{mol} \mathrm{mL}^{-1}$ & $\mathrm{mg} \mathrm{mL}^{-1}$ & $\mu \mathrm{mol} \mathrm{mL^{-1 }}$ \\
\hline 1.00 & $1.44 \cdot 10^{-2}$ & 0.338 & 1.380 \\
\hline 0.75 & $1.08 \cdot 10^{-2}$ & 0.253 & 1.04 \\
\hline 0.50 & $7.21 \cdot 10^{-3}$ & 0.169 & 0.692 \\
\hline 0.25 & $3.58 \cdot 10^{-3}$ & $8.40 \cdot 10^{-2}$ & 0.344 \\
\hline 0.05 & $7.29 \cdot 10^{-4}$ & $1.70 \cdot 10^{-2}$ & $7.00 \cdot 10^{-2}$ \\
\hline 0.001 & $1.46 \cdot 10^{-5}$ & $3.40 \cdot 10^{-4}$ & $1.40 \cdot 10^{-3}$ \\
\hline
\end{tabular}

Figure S31. Left. Peaks obtained with the software ImageJ using different concentration of dispensed G4-biotin dendrimers (9:1, water:DMF) as control line, after interaction with $5.9010^{-11} \mathrm{~mol} \mathrm{~L}^{-1}$ streptAv-AuNPs. $\mathrm{n}=3$. Right. Table contents: moles of dendrimers and biotin moieties in $\mathrm{mg} \mathrm{mL}^{-1}$ and of $\mu \mathrm{mol} \mathrm{mL} \mathrm{m}^{-1}$ solutions. 


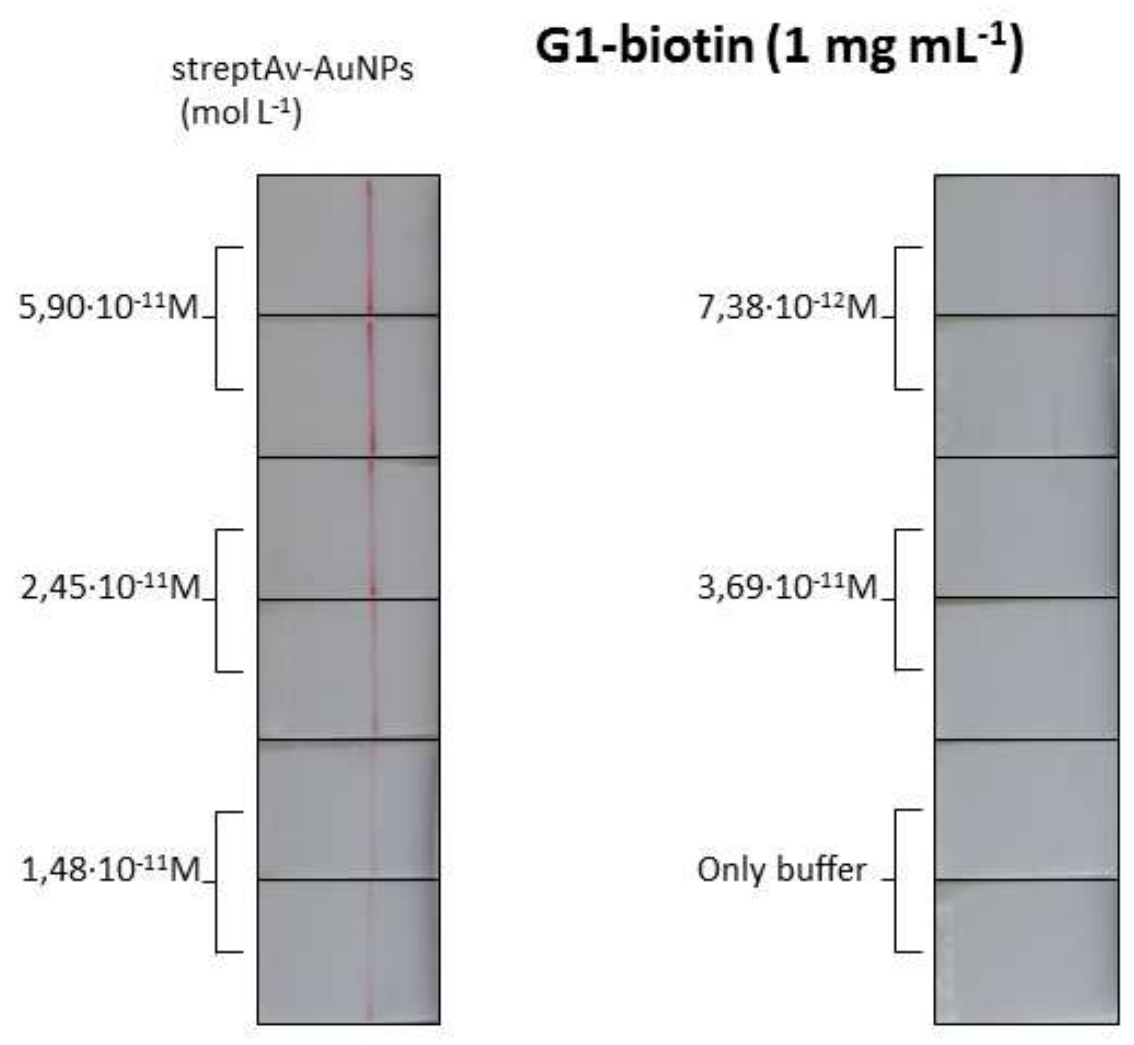

Figure S32. LFA images using different concentration of signal generating system (streptAv-AuNPs) in the conjugation pad and $1 \mathrm{mg} \mathrm{mL}^{-1}$ of dispensed G1-biotin dendrimer (9:1, water:DMF) as control line. $\mathrm{n}=2$. 


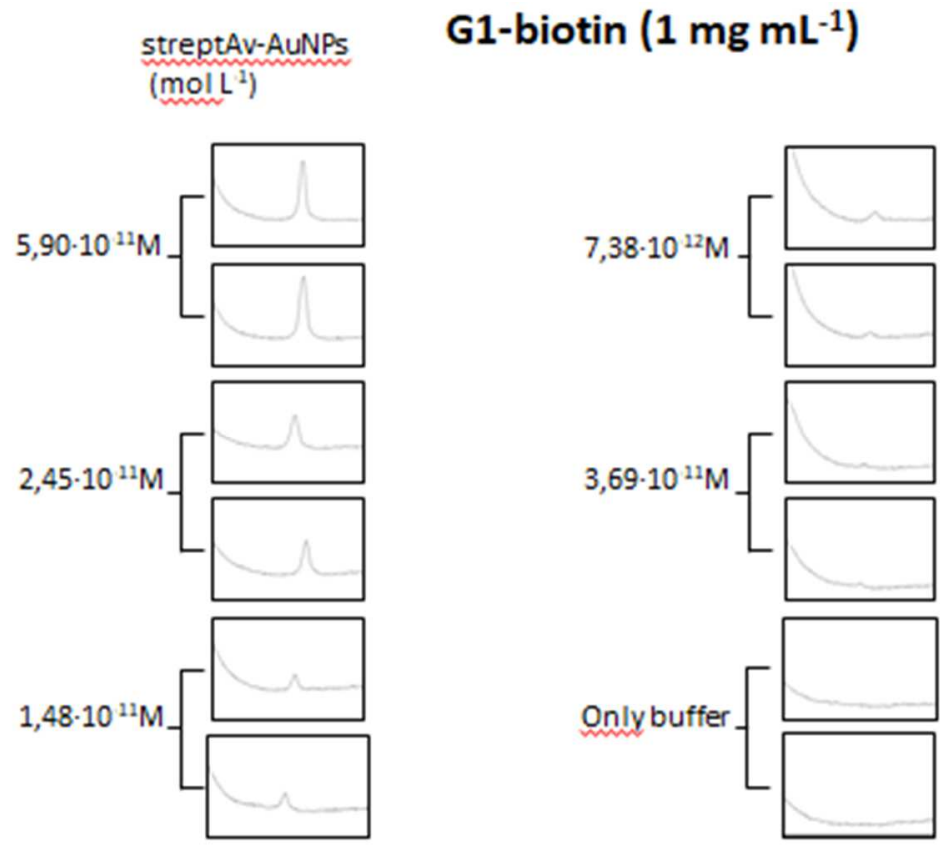

Figure S33. Peaks obtained with the software ImageJ using different concentration of signal generating system (streptAv-AuNPs) in the conjugation pad and $1 \mathrm{mg} \mathrm{mL}^{-1}$ of dispensed G1-biotin dendrimer (9:1, water:DMF) as control line. $\mathrm{n}=2$. 


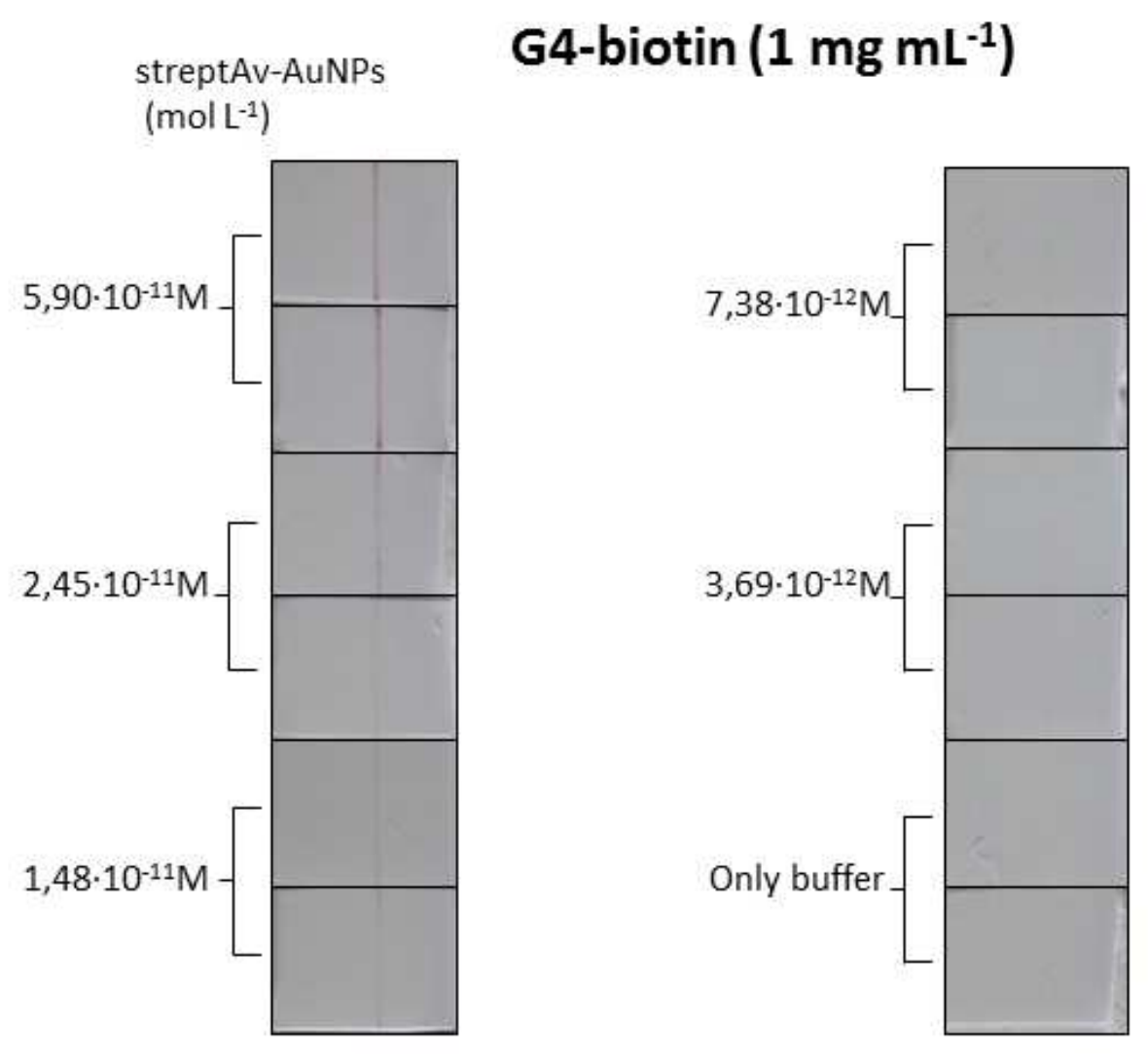

Figure S34. LFA images using different concentration of signal generating system (streptAv-AuNPs) in the conjugation pad and $1 \mathrm{mg} \mathrm{mL}^{-1}$ of dispensed G4-biotin dendrimer (9:1, water:DMF) as control line. $\mathrm{n}=2$. 


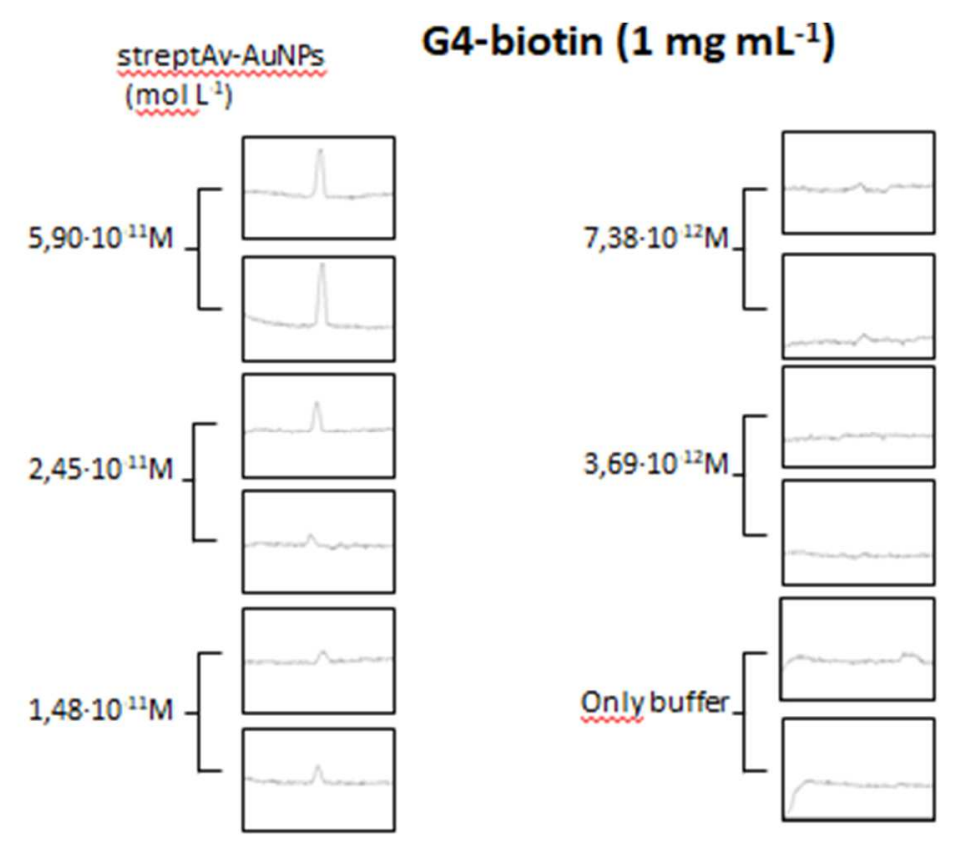

Figure S35. Peaks obtained with the software ImageJ using different concentration of signal generating system (streptAv-AuNPs) in the conjugation pad and $1 \mathrm{mg} \mathrm{mL}^{-1}$ of dispensed G4-biotin dendrimer (9:1, water:DMF) as control line. $\mathrm{n}=2$. 


\section{G1-biotin}
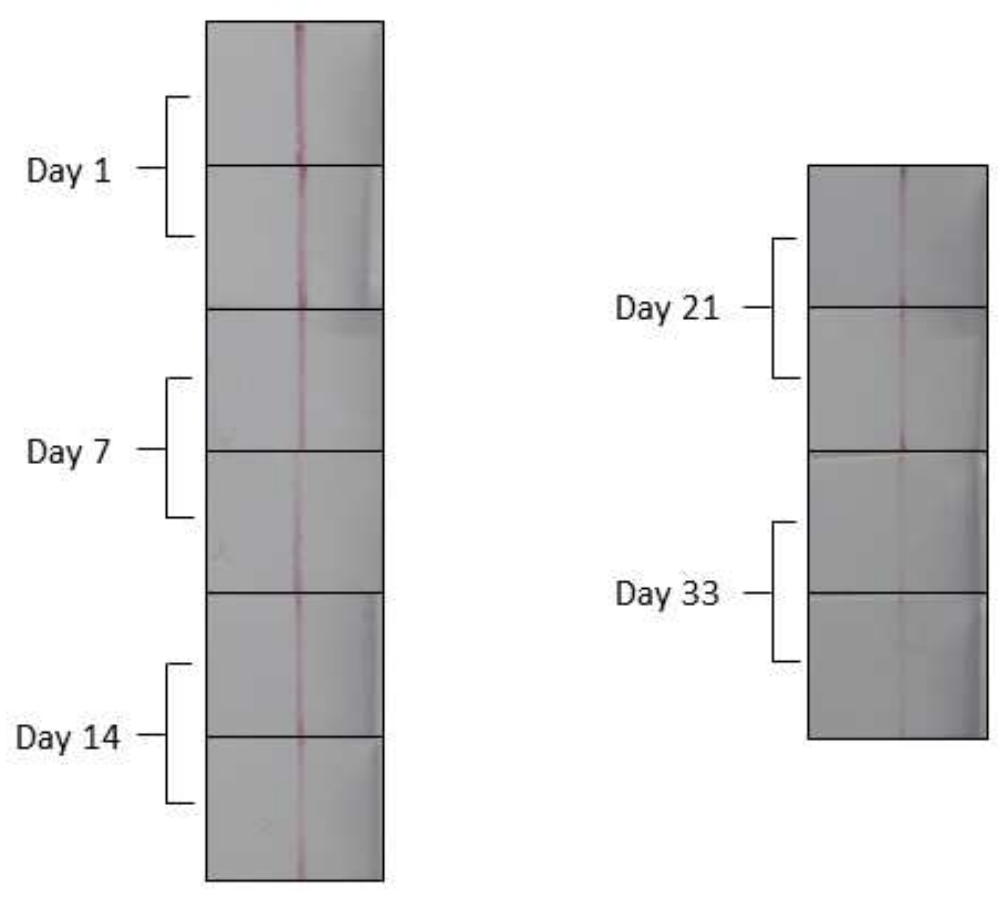

Figure S36. Stability study at a $1 \mathrm{mg} \mathrm{mL}^{-1}$ of dispensed G1-biotin dendrimers solutions

(9:1, water:DMF) as control line and a concentration of signal generating system (streptAv-AuNPs) in the conjugation pad of $2.4510^{-11} \mathrm{~mol} \mathrm{~L}^{-1} \cdot \mathrm{n}=2$. 


\section{G1-biotin}
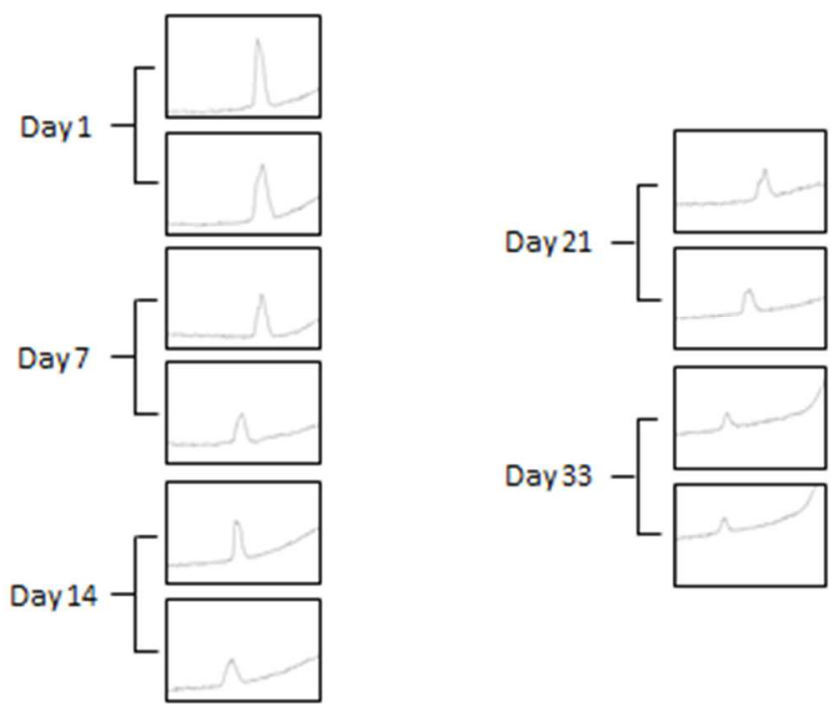

Figure S37. Peaks obtained with the software ImageJ of the stability study at a $1 \mathrm{mg}$ $\mathrm{mL}^{-1}$ of dispensed G1-biotin dendrimers solutions (9:1, water:DMF) as control line and a concentration of signal generating system (streptAv-AuNPs) in the conjugation pad of $2.4510^{-11} \mathrm{~mol} \mathrm{~L}^{-1} \cdot \mathrm{n}=2$. 


\section{G4-biotin}
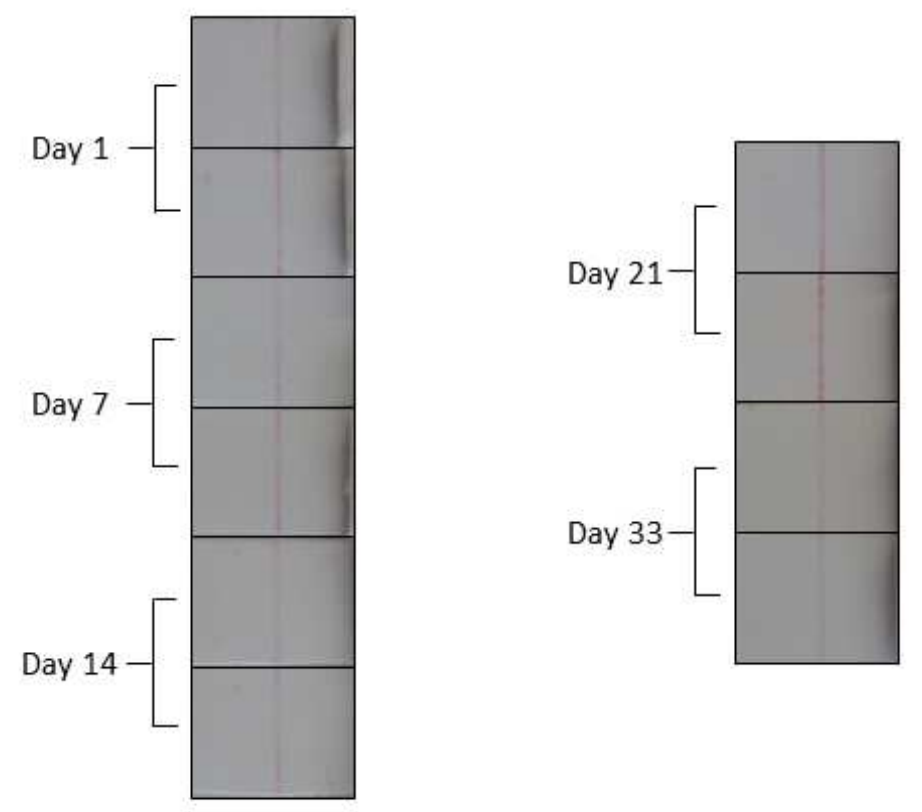

Figure S38. Stability study at a $1 \mathrm{mg} \mathrm{mL}^{-1}$ of dispensed G4-biotin dendrimers solutions (9:1, water:DMF) as control line and a concentration of signal generating system (streptAv-AuNPs) in the conjugation pad of $2.4510^{-11} \mathrm{~mol} \mathrm{~L}^{-1} \cdot \mathrm{n}=2$. 


\section{G4-biotin}
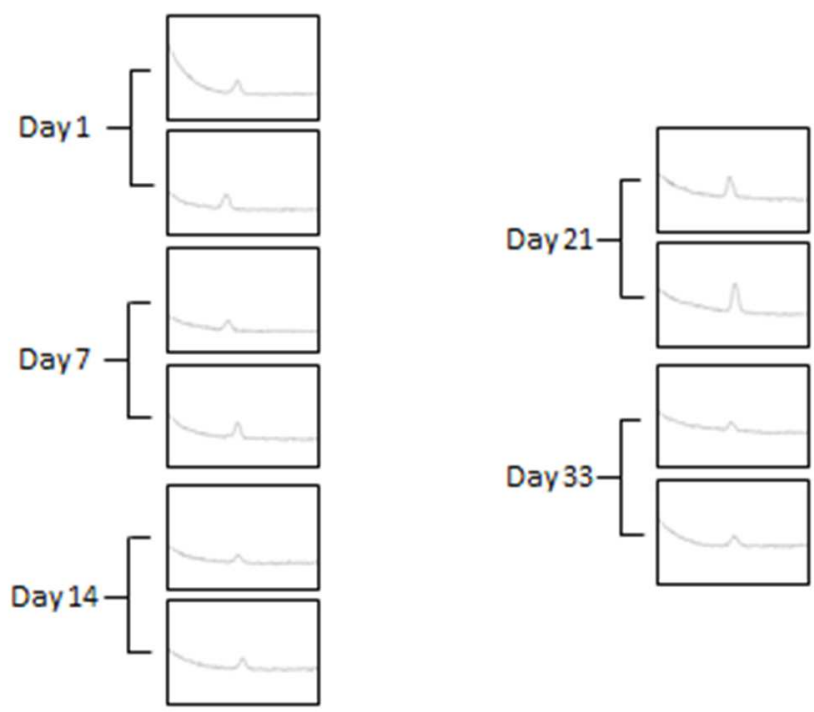

Figure S39. Peaks obtained with the software ImageJ of the stability study at a $1 \mathrm{mg}$ $\mathrm{mL}^{-1}$ of dispensed G4-biotin dendrimers solutions (9:1, water:DMF) as control line and a concentration of signal generating system (streptAv-AuNPs) in the conjugation pad of $2.4510^{-11} \mathrm{~mol} \mathrm{~L}^{-1} \cdot \mathrm{n}=2$. 
S40. Development of the lateral flow strips for the detection of a double-tagged DNA

The preparation and assembly of the strip was performed as above, but with the addition of a test line composed by the antiDIG antibody.

In order to absorb all the components on the nitrocellulose strips, a Lateral Flow Reagent Dispenser from Claremont Bio (Upland, CA) combined with the KDS Legato $^{\text {TM }} 200$ series syringe pump fromKD Scientific Inc. (Holliston, MA) was used to obtain a straight and well define line.

Before starting, two canals of the dispenser, one for the antiDIG antibody $\left(0.50 \mathrm{mg} \mathrm{mL}^{-}\right.$ $\left.{ }^{1}\right)$ placed in the test line and the other for dendrimer $\left(0.50 \mathrm{mg} \mathrm{mL}^{-1}\right)$ in the control line, were cleaned with $5 \mathrm{~mL}$ of water, methanol, water and air, respectively. $150 \mu \mathrm{L}$ of the desired solution was taken and placed in the dispenser at a rate of $38 \mu \mathrm{L} \mathrm{min}{ }^{-1}$. Both solutions were run through the channel until the end of the nitrocellulose, forming two perfect, defined lines (test and control). The dispenser was cleaned again and the strip is left to dry for approximately 30 minutes.

Once the dendrimer and the antiDIG were deposited on the nitrocellulose, the LFA strip was prepared by following procedure:

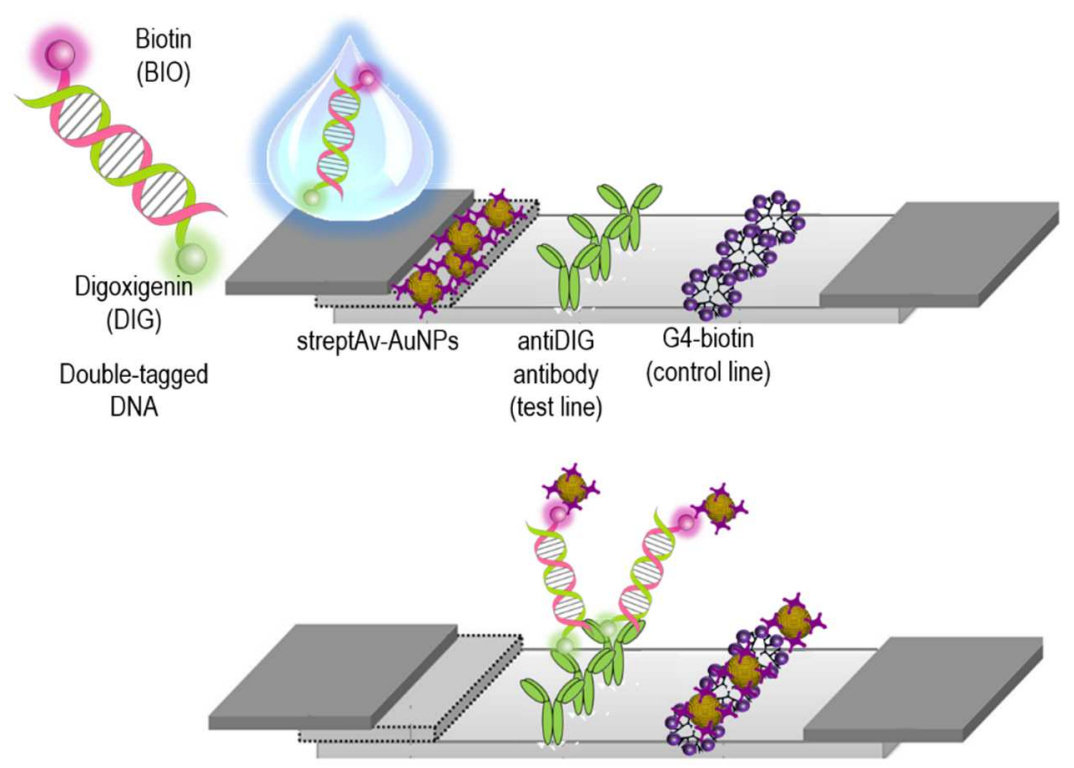

Preparation of conjugate pad: a solution of $2.5 \mu \mathrm{L}$ of commercially available InnovaCoat ${ }^{\circledR}$ GOLD $40 \mathrm{~nm}$ (10 OD) Streptavidin gold nano-particles (streptAvAuNPs) (purchased from Innova Bios-ciences, Cambridge, UK) and $47.5 \mu 1$ of conjugate buffer $\left(2 \mathrm{mmol} \cdot \mathrm{L}^{-1}\right.$ borate $\mathrm{pH}=7,10 \% \mathrm{w} / \mathrm{v}$ sucrose $)$ was dispensed in the glass fiber conjugate pad. Then it was dried for approximately 2 hours at RT.

Finally, the strips were assembled in the usual way on the adhesive backing card. 
Once the strip is prepared, $50 \mu \mathrm{L}$ of double-tagged DNA $\left(300 \mathrm{ng} \mathrm{mL}^{-1}\right)$ from the double-tagging PCR was added on the sample pad, followed by the addition of $100 \mu \mathrm{L}$ of running buffer $\left(0.01 \mathrm{~mol} \mathrm{~L}^{-1}\right.$ phosphate buffer $\mathrm{pH} 7.4,1 \% \mathrm{BSA}, 0.05 \%$ Tween 20$)$ were deposited in the sample pad. Further aliquots of $50 \mu \mathrm{L}$ running buffer was added until the conjugate pad was completely white, indicating the complete remove of the streptAv-AuNPs. The streptAv-AuNPs thus reacted with the BIO-tag of the amplicons from E. Coli. As the product moved along the strip, the streptAv-AuNPs/amplicon was captured by the specific antibody on the test line (antiDIG). A valid test was considered when the remaining streptAv-AuNPs reacted with a biotinylated dendrimer as a positive control at the control line. The visual readout was thus achieved as well as the interpretation of the results. Two well-defined lines were thus observed on the test and the control line.

At the same time, a negative control (PCR negative control with not E. Coli as template) was also run. In this instance, only one line was accordingly observed. 